\title{
ONREL
}

\section{Retail Building Guide for Entrance Energy Efficiency Measures}
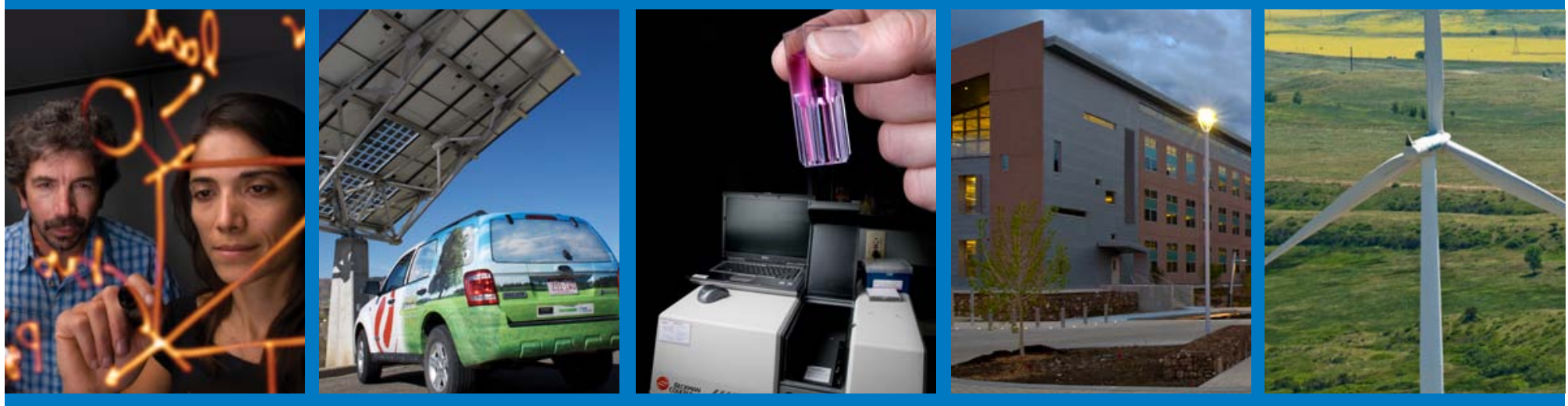

NREL is a national laboratory of the U.S. Department of Energy, Office of Energy Efficiency and Renewable Energy, operated by the Alliance for Sustainable Energy, LLC. 



\section{Contents}

Overview.

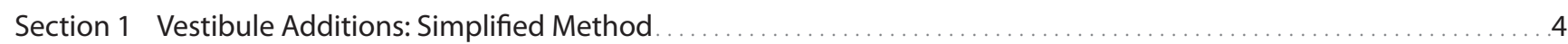

Section 2 Vestibule Additions: Simulation-Based Method .................................................... 10

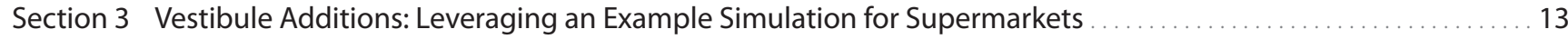

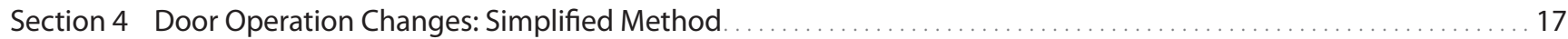

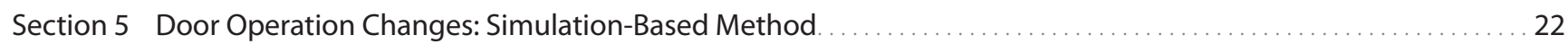

Section 6 Door Operation Changes: Leveraging an Example Simulation for Large Retail Buildings ..................... 25

References

Appendix A

Vestibule Additions: Background and Development of Equations.

Appendix B

Door Operation Changes: Background and Development of Equations

Appendix C

Additional Considerations and Tips for Choosing Entrance Strategies.

Appendix D

DOE Climate Zones and Representative Cities

Appendix E - Worksheet for Section 1

Vestibule Additions: Simplified Method

Appendix F - Worksheet for Section 3

Vestibule Additions: Leveraging an Example Simulation for Supermarkets

Appendix G - Worksheet for Section 4

Door Operation Changes: Simplified Method

Appendix $\mathrm{H}$ - Worksheet for Section 6

Door Operation Changes: Leveraging an Example Simulation for Large Retail Buildings . .

\section{Nomenclature}

$\begin{array}{ll}\text { ASHRAE } & \text { American Society of Heating, Refrigerating and Air-Conditioning Engineers } \\ \text { CFM } & \text { cubic feet per minute } \\ \text { COP } & \text { coefficient of performance } \\ \text { DOE } & \text { U.S. Department of Energy } \\ \text { NREL } & \text { National Renewable Energy Laboratory } \\ \text { PNNL } & \text { Pacific Northwest National Laboratory } \\ \text { TMY } & \text { Typical Meteorological Year }\end{array}$

\section{Acknowledgments}

This document was produced in collaboration with the Commercial Building Energy Alliances, a partnership sponsored by the Department of Energy (DOE). The authors would like to thank the DOE Building Technologies Program for its support. This document was prepared for DOE under Task BEC7.1311.

The Center for Electricity, Resources, and Building Systems Integration at NREL led the production of this guide. The instructions are based on analysis led by Justin Stein, and the guide was assembled by Justin Stein and Feitau Kung. The authors acknowledge the work of Eric Bonnema and Lesley Herrmann in developing earlier large retail building models that were modified for this study. The authors thank Michael Deru, Daniel Studer, William Livingood, Matt Leach, and Rois Langner for their technical assistance and reviews.

Several retail industry representatives contributed guidance that informed the strategies discussed in this guide. In particular, Ben Ferrell and Paul Holliday of Lowe's, Pat Hagan of Wawa, and David Oshinski of The Home Depot provided informative data about building system and operation assumptions. Thank you to these and other members of the Retailer Energy Alliance's Whole-Building Systems Project Team for your feedback and support. 

Carefully designed and operated building entrances can help control energy consumption and operating costs, as well as increase occupant comfort. Historically, designers and operators have had little information about how much energy such changes can save.

This guide addresses the previous resource gap by synthesizing results from multiple research efforts into methods and examples that can be used by retail building engineers to produce preliminary savings estimates. It provides step-by-step instructions about how to estimate the energy and cost savings of two types of entrance energy efficiency measures: vestibule additions and door operation changes.

Examples show a whole-building energy savings potential range of $1 \%-9 \%$ for these two measures. For instance, an example retail building in Chicago could save $\$ 2,000$ annually with the addition of a vestibule'. Another example building in Chicago with a large bay door could save $\$ 5,400$ annually with a door operation change ${ }^{2}$.

The measures can be applied to the following types of entrances:

For vestibule additions: Doors, such as typical customer entrance doors, that open and close as individuals pass through.

For door operation changes: Doors, such as customer doors used for large item pickups or shipping and receiving, which are left open for extended periods. Measures may include changes to when or how long the doors are open and changes to the effective door area.

This document reflects collaborative input from the members of the Whole-Building Systems Project Team in DOE's Retailer Energy Alliance.

\section{Options for Generating Initial Savings Estimates}

For each measure, the guide provides several approaches:

Option A - Use the Simplified Method: You can use the equations and tables provided in this guide to generate initial energy and cost savings potential estimates. The instructions reference a combination of findings from a National Renewable Energy Laboratory (NREL) analysis of two specific building types and research by other institutions.

Applicability: Free-standing retail buildings. Equations are provided for 10 climate zones.

Advantages: Relatively quick and easy.

Disadvantages: Little freedom to enter site-specific information; does not capture system interactions.

Option B - Perform Whole-Building Energy Simulation: You can use your estimated infiltration rates with whole-building energy simulation to capture system interactions and site-specific conditions. The energy impact of infiltration through entrances depends on a variety of factors, including building size; the time of day when doors are open; whether the heating, ventilation, and air-conditioning (HVAC) system is heating or cooling when doors are open; and whether humidity is a concern.

Applicability: Free-standing retail buildings.

Advantages: Freedom to enter site-specific information; captures system interactions.

Disadvantages: Requires more time and effort than other options; may require external expertise.

Option C - Leverage Examples From Research: Two simulation cases are provided as examples. If your building is similar to one, you can use the instructions to adapt the example results and estimate the energy and cost implications for your scenarios. These theoretical models represent generic building types:

\section{Supermarket Building Model With a Vestibule Addition}

The supermarket building model is $45,000 \mathrm{ft}^{2}$. It includes a total sales area of $25,000 \mathrm{ft}^{2}$, refrigerated cases throughout the sales area, and HVAC equipment with humidity controls.

\footnotetext{
1 The vestibule addition includes sliding doors, where the interior and exterior doors are directly across from each other. The example assumes the building is open 24 hours per day, the main entrance has a $42-\mathrm{ft}^{2}$ doorway, and an average of 110 people enter or exit the door per hour. The savings also depend on assumptions for wind at the site.

2 The baseline case includes a 20-ft wide by 12-ft high bay door that is open on average for 3 hours in the morning, typically from 6:00 a.m. to 9:00 a.m. The alternative case changes the default opening height to $7 \mathrm{ft}$ and allows the door to open to the full height of $12 \mathrm{ft}$ when necessary. 
Overview

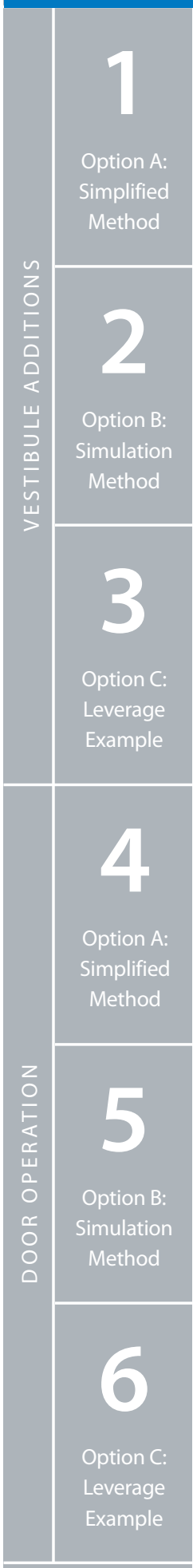

References

Applicability: Supermarket buildings of similar scale and operation. Results are provided for six climate zones.

Advantages: Relatively quick and easy. Captures system interactions for a generic example.

Disadvantages: Little freedom to enter site-specific information or capture site-specific system interactions. Large Retail Building Model With Door Operation Changes

The large retail building model is $110,000 \mathrm{ft}^{2}$. It includes a total sales area of $87,500 \mathrm{ft}^{2}$ with no refrigerated cases. It was designed to represent a home improvement store with a bay door for customers purchasing large items.

Applicability: Large retail building of similar scale, use, and operation. Results are provided for six climate zones.

Advantages: Relatively quick and easy. Captures system interactions for a generic example.

Disadvantages: Little freedom to enter site-specific information or capture site-specific system interactions.

Figure 1 and Figure 2 provide decision trees that direct you to sections of interest for each measure and approach.

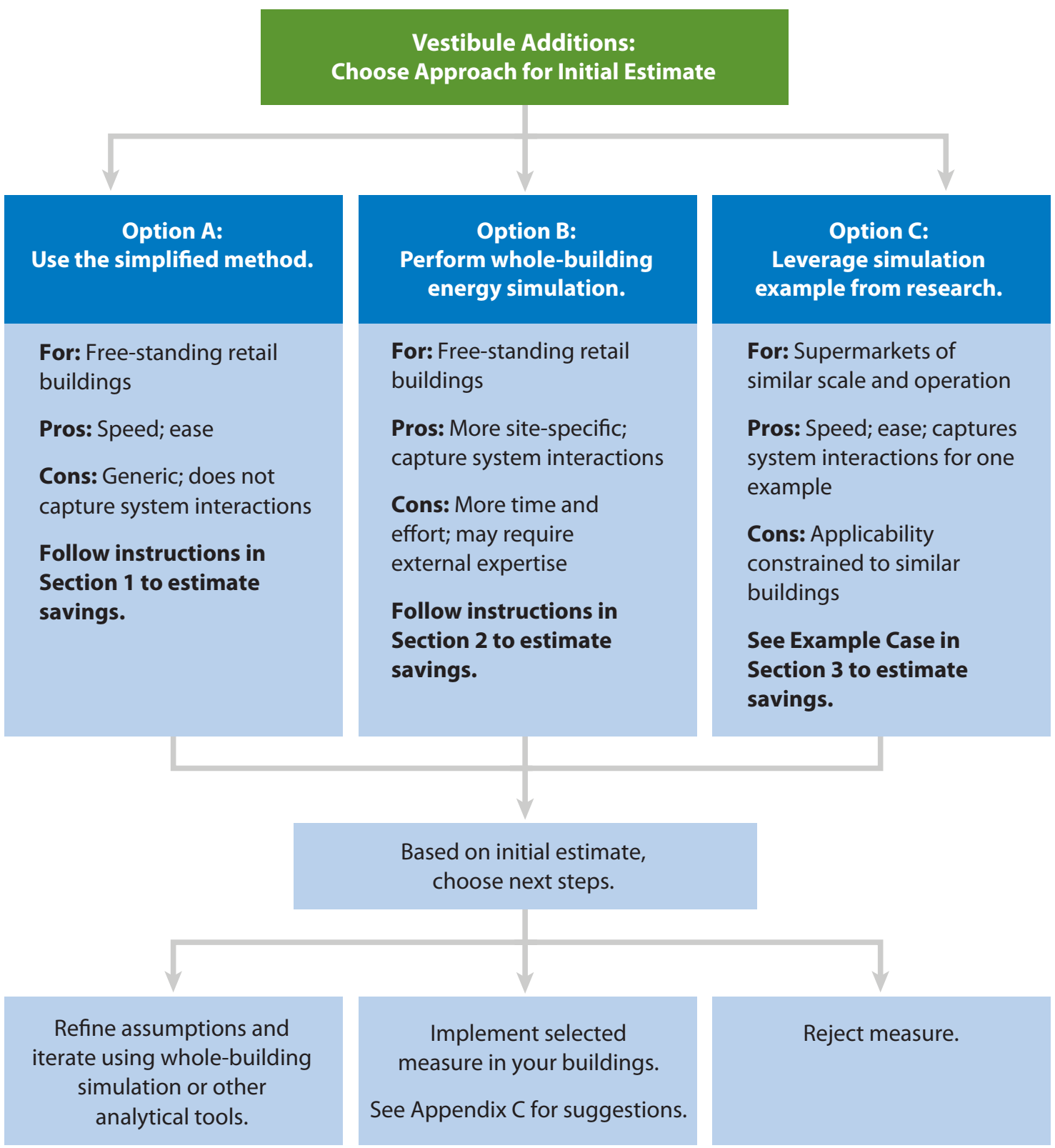

Figure 1. Decision tree for vestibule additions 
Door Operation Changes:

Choose Approach for Initial Estimate

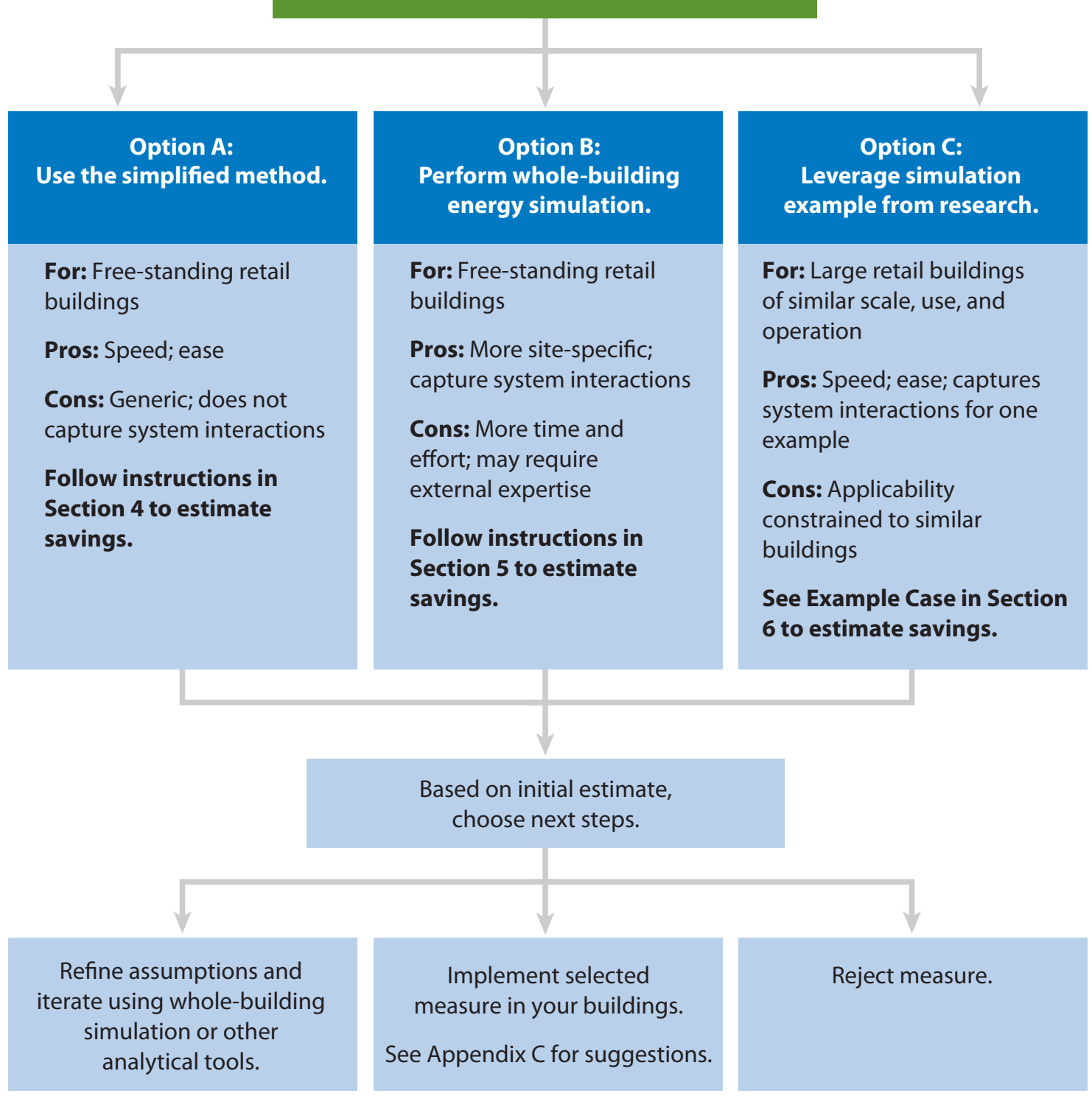

Overview

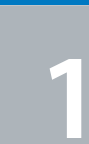

Option A:

Simplified

Method

Pros: More site-specific;

Pros: Speed; ease; captures system interactions for one

Cons: Applicability constrained to similar

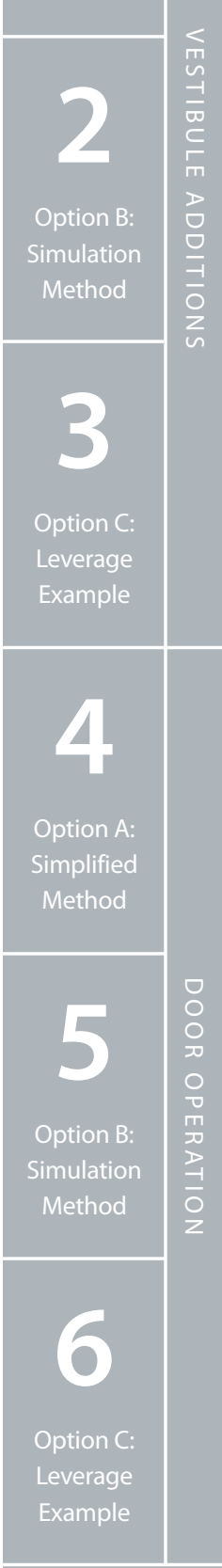

Figure 2. Decision tree for door operation changes 


\section{Section 1}

\section{Vestibule Additions: Simplified Method}

Overview

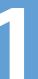

Option A:

Simplified

Method

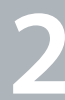

Option B:

Simulation

Method

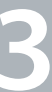

Option C.

Leverage

Example

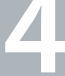

Option A:

Simplified

Method

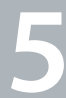

Option B:

Simulation

Method

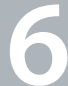

Option C:

Leverage

Example

References
This method applies to..

Building type: Free-standing retail buildings. Equations are provided for 10 climate zones.

How the door is used: The door opens and closes as individuals pass through, as with a typical customer entrance door. (This excludes doors left open for extended periods.)

Door location: At the perimeter of a conditioned space.

Compare to other methods in this guide...

Advantages: Relatively quick and easy.

Disadvantages: Little freedom to enter site-specific information; does not capture system interactions.

\section{Introduction}

Vestibules can reduce infiltration at entrances where:

- Doors open and close as individuals pass through, rather than being left open for extended periods.

- Traffic passes frequently into conditioned spaces.

- Revolving doors are not practical.

You can use this section to estimate the energy and cost implications associated with vestibule additions.

Appendix A provides details about how the steps and equations in this section were developed.

\section{Instructions}

Follow these instructions to first estimate infiltration rates associated with your current door use scenario. Then proceed with the simplified calculations to complete the savings estimate. (A worksheet is provided in Appendix E to supplement this section.)

\section{Step 1 Estimate an airflow coefficient based on door uses per hour}

Use Equations 1-1 through 1-4 to estimate the corresponding airflow coefficients for cases with and without a vestibule and cases with different door types and orientations. The door use rate (people per hour) is the average number of one-way trips through the door.

This value should be the annual average door use rate during entrance operating hours. Once you define the entrance operating hours, you need to use the same value for this parameter throughout the section.

If you do not know the actual door use rate, you can use the average number of retail sales transactions per hour as an estimate.

Example: During a typical week, a retail building has 3,500 transactions. There is one customer entrance, which is unlocked between 10:00 a.m. and 8:00 p.m. each day, for 70 entrance operating hours per week. This yields an average of 50 transactions per hour during entrance operating hours. Because this is the only customer entrance, the retailer assumes that 50 people on average enter and exit the door per hour. This translates to 100 one-way trips per hour, or a door use rate of 100 people per hour. 
For a case without a vestibule:

$$
\mathrm{C}_{\mathrm{A}}=-0.0024 \times \mathrm{PPH}^{2}+3.813 \times \mathrm{PPH}-4.219
$$

For a vestibule with swinging doors:

$$
\mathrm{C}_{\mathrm{A}}=-0.0016 \times \mathrm{PPH}^{2}+2.722 \times \mathrm{PPH}-8.591
$$

For a vestibule with sliding doors, where the inner and outer doors are across from each other:

$$
\mathrm{C}_{\mathrm{A}}=-0.0013 \times \mathrm{PPH}^{2}+2.479 \times \mathrm{PPH}-7.518
$$

For a vestibule with sliding doors, where the outer doors are on the left or right side of the vestibule:

$$
\mathrm{C}_{\mathrm{A}}=-0.0012 \times \mathrm{PPH}^{2}+2.229 \times \mathrm{PPH}-6.637
$$

where:

$$
\begin{array}{lll}
\mathrm{C}_{\mathrm{A}} & = & \text { airflow coefficient }\left((\mathrm{cfm}) / \mathrm{ft}^{2} /(\mathrm{in} . \text { of water })^{0.5}\right) \\
\mathrm{PPH} & = & \text { annual average door use rate during entrance operating hours (people per hour) }
\end{array}
$$

The equations are second-order polynomial best fit lines that summarize selected airflow coefficients from Yuill (1996). See Appendix A for details.

\section{Step 2 Identify a pressure factor}

Choose your pressure factor, $R_{\mathrm{P}}$, from Table 1-1. The methodology from the section titled "Air Leakage through Automatic Doors" in Chapter 16 of the ASHRAE Handbook of Fundamentals (ASHRAE 2009) was used to derive the values. You can adjust the conservatism or aggressiveness of your infiltration estimate by selecting different assumptions for average wind speed and local wind pressure coefficient, $C_{p}$. For more methodology details, see Appendix A.

Table 1-1. Pressure Factors $\left(R_{P}\right)$

\begin{tabular}{|c|c|c|}
\hline $\begin{array}{c}\text { Average Wind Speed } \\
\text { When Door Is in Use } \\
(\mathrm{mph})\end{array}$ & $\begin{array}{c}\text { Option 1: } \\
\text { Assume Wind Pressure Coefficient } \\
\text { With Moderate Impact on Infiltration } \\
\left(C_{p}=0.45\right)\end{array}$ & $\begin{array}{c}\text { Option 2: } \\
\text { Assume Wind Pressure Coefficient } \\
\text { With Maximum Impact on Infiltration } \\
\left(C_{p}=0.70\right)\end{array}$ \\
\hline 5 & 0.07 & 0.09 \\
\hline 10 & 0.15 & 0.18 \\
\hline 15 & 0.22 & 0.28 \\
\hline 20 & 0.29 & 0.37 \\
\hline
\end{tabular}

\section{Step 3 Estimate your infiltration rates}

Apply your airflow coefficients, pressure factor, and door area in Equation 1-5 (ASHRAE 2009). Estimate your infiltration rates (cfm) for cases with and without a vestibule.

$$
C F M=C_{A} \times A \times R_{P}
$$

where:

$\begin{array}{lll}\mathrm{CFM} & = & \text { infiltration rate }(\mathrm{cfm}) \\ \mathrm{C}_{\mathrm{A}} & = & \text { airflow coefficient }\left((\mathrm{cfm}) / \mathrm{ft}^{2} /(\mathrm{in} . \text { of water })^{0.5}\right) \\ \mathrm{A} & = & \text { area of the door opening }\left(\mathrm{ft}^{2}\right) \\ \mathrm{RP}_{\mathrm{P}} & = & \text { pressure factor }\left((\mathrm{in} . \text { of water })^{0.5}\right)\end{array}$


The flow-normalized climate factor is a user input that will be used in Equation 1-6. This input accounts for variations in infiltration rate by climate, and is normalized by the infiltration flow rate through the door. Use Table 1-2 to select the appropriate factor for your location. Choose the city with the most similar climate. (See Appendix D for a U.S. map of the DOE climate zones and representative cities.)

Example: A retail building is located in Columbus, Ohio. The building owner uses Appendix D and Table 1-2 to determine that Chicago, Illinois, has the most similar climate as it is in the same climate zone. The owner selects the Climate Zone 5A value, $F_{C F}=0.00994$.

Table 1-2. Flow-Normalized Climate Factors $\left(\mathrm{F}_{\mathrm{CF}}\right)$

Option A:

Simplified

Method

\begin{tabular}{|c|c|c|}
\hline \multicolumn{2}{|c|}{ Location } & \multirow{2}{*}{$\begin{array}{l}\text { Flow-Normalized Climate Factors, } F_{\mathrm{CF}} \\
\text { (MMBtu·day/h/cfm) }\end{array}$} \\
\hline Climate Zone & Reference City & \\
\hline $1 \mathrm{~A}$ & Miami, Florida & 0.00051 \\
\hline $2 A$ & Houston, Texas & 0.00193 \\
\hline $3 A$ & Atlanta, Georgia & 0.00501 \\
\hline $3 B$ & Las Vegas, Nevada & 0.00389 \\
\hline $4 \mathrm{~A}$ & Baltimore, Maryland & 0.00761 \\
\hline $4 C$ & Seattle, Washington & 0.00775 \\
\hline $5 A$ & Chicago, Illinois & 0.00994 \\
\hline $5 B$ & Boulder, Colorado & 0.00966 \\
\hline $6 \mathrm{~A}$ & Minneapolis, Minnesota & 0.01185 \\
\hline 7 & Duluth, Minnesota & 0.01515 \\
\hline
\end{tabular}

\section{Step 5 Identify a time-of-day multiplier}

If you know your door typically opens and closes within specific timeframes, you can use the time-of-day multipliers in Table 1-3 to adjust your estimate. Otherwise, assume a time-of-day multiplier of 1 . The differences between the average outdoor and indoor temperatures for the specified timeframes were used to develop the multipliers.

Example: A retail building entrance in Columbus, Ohio, is typically open to customers from 7:00 a.m. to 9:00 p.m. The owner uses Appendix D and Table 1-3 and observes that Chicago, Illinois, has the most similar climate as it is in the same climate zone. The owner also notes that the average entrance operating hours (7:00 a.m. to 9:00 p.m.) overlap three timeframes in the table: 6:00 a.m. to 12:00 p.m., 12:00 p.m. to 6:00 p.m., and 6:00 p.m. to 12:00 a.m. The time-of-day multipliers for these timeframes are 0.95, 0.83, and 1.05 , respectively.

Option 1: The owner could calculate a simple average of these three time-of-day multipliers to yield $M_{T}=0.94$.

Option 2: The owner could calculate a weighted average. Of the 14 entrance operating hours per day, 5 fall between 6:00 a.m. and 12:00 p.m., 6 fall between 12:00 p.m. and 6:00 p.m., and 3 fall between 6:00 p.m. and 12:00 a.m. With this option, $M_{T}=0.95 \times(5 / 14)+0.83 \times(6 / 14)+1.05 \times(3 / 14)=0.92$.

(If this example were continued into Step 6, the entrance operating hours, $H$, in Equation 1-6 would equal 14 hours per day.) 


\begin{tabular}{|c|c|c|c|c|c|}
\hline \multicolumn{2}{|r|}{ Location } & \multicolumn{4}{|c|}{ Timeframe That Best Aligns With Entrance Operating Hours } \\
\hline $\begin{array}{l}\text { Climate } \\
\text { Zone }\end{array}$ & Reference City & $\begin{array}{c}\text { 12:00 a.m. to } \\
\text { 6:00 a.m. }\end{array}$ & $\begin{array}{l}\text { 6:00 a.m. to } \\
\text { 12:00 p.m. }\end{array}$ & $\begin{array}{l}\text { 12:00 p.m. to } \\
\text { 6:00 p.m. }\end{array}$ & $\begin{array}{l}\text { 6:00 p.m. to } \\
12: 00 \text { a.m. }\end{array}$ \\
\hline $1 \mathrm{~A}$ & Miami, Florida & 0.21 & 1.14 & 1.84 & 0.81 \\
\hline $2 \mathrm{~A}$ & Houston, Texas & 1.46 & 1.15 & 0.23 & 1.16 \\
\hline $3 A$ & Atlanta, Georgia & 1.38 & 1.08 & 0.60 & 0.94 \\
\hline 3B & Las Vegas, Nevada & 1.45 & 0.96 & 0.36 & 1.23 \\
\hline $4 \mathrm{~A}$ & Baltimore, Maryland & 1.27 & 0.98 & 0.71 & 1.04 \\
\hline $4 C$ & Seattle, Washington & 1.33 & 0.97 & 0.71 & 0.99 \\
\hline $5 A$ & Chicago, Illinois & 1.17 & 0.95 & 0.83 & 1.05 \\
\hline $5 B$ & Boulder, Colorado & 1.41 & 0.89 & 0.63 & 1.06 \\
\hline $6 \mathrm{~A}$ & Minneapolis, Minnesota & 1.16 & 1.00 & 0.85 & 0.99 \\
\hline 7 & Duluth, Minnesota & 1.18 & 0.99 & 0.80 & 1.02 \\
\hline
\end{tabular}

\section{Step 6 Estimate your energy savings potential}

Use Equation 1-6 to estimate the whole-building energy savings potential associated with your vestibule addition.

$$
E_{\text {savings }}=F_{C F} \times M_{T} \times H \times\left(C F M_{C}-C F M_{P}\right)
$$

where:

$\begin{array}{lll}\mathrm{E}_{\text {savings }} & = & \text { annual whole-building energy savings potential (MMBtu) } \\ \mathrm{F}_{\mathrm{CF}} & = & \text { flow-normalized climate factor (MMBtu-day/h/cfm; see Table 1-2) } \\ \mathrm{M}_{\mathrm{T}} & = & \text { time-of-day multiplier (dimensionless; see Table 1-3) } \\ \mathrm{H} & = & \text { entrance operating hours per day, annual average (h/day) } \\ \mathrm{CFM}_{\mathrm{C}} & = & \text { average infiltration rate during hours of use for current strategy (cfm) } \\ \mathrm{CFM} & = & \text { average infiltration rate during hours of use for proposed strategy }(\mathrm{cfm})\end{array}$

Example: Continuing the example from Step 5, a retail building entrance in Columbus, Ohio, is open on average from 7:00 a.m. to 9:00 p.m. The entrance operating hours, $H$, in Equation 1-6 would equal 14 hours per day. Use this in Equation 1-6 along with the values for $F_{C F}, M_{T}$, and CFM that you found in previous steps.

\section{Step $7 \quad$ Select cooling and heating fraction multipliers}

Use Table 1-4 to identify the appropriate cooling and heating fraction multipliers that correspond to your location and the time your door is typically in use. Choose the city with the most similar climate. (See Appendix D for a U.S. map of the DOE climate zones and representative cities.) The multipliers reflect the proportion of energy savings potential that is attributable to cooling or heating energy savings.

Assuming $E_{\text {savings }}$ is positive in Step 6, a positive cooling (or heating) fraction multiplier in Table 1-4 indicates that the proposed strategy will reduce the cooling (or heating) load.

The cooling fraction multiplier is occasionally a low negative number. In such cases, if $\mathrm{E}_{\text {savings }}$ is positive, the proposed strategy will increase the cooling load slightly, but the net whole-building energy consumption will still decrease.

As in the example from Step 5, if the average entrance operating hours overlap multiple timeframes, a cooling fraction multiplier and a heating fraction multiplier can be estimated in Step 7 by performing either a simple average or a weighted average of values from applicable timeframes in the table. 
Table 1-4. Entrance Cooling ( $\left.\mathrm{M}_{\mathrm{CLG}}\right)$ and Heating $\left(\mathrm{M}_{\mathrm{HTG}}\right)$ Fraction Multipliers for Vestibule Equations

Overview

1

Option A:

Simplified

Method

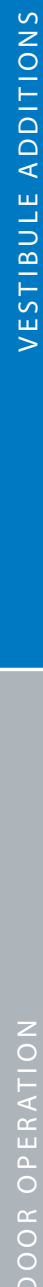

Option B:

Simulation

Method

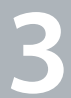

Option C:

Leverage

Example

4

Option A:

Simplified

Method

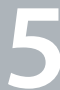

Option B:

Simulation

Method

6

Atlanta,
Georgia

Miami,

Florida

Houston,

Texas

3B Las Vegas,

Nevada

$4 \mathrm{~A}$

Baltimore,

Maryland

4C

Seattle,

Washington

$5 A$

Chicago,

Illinois

5B Boulder,

Colorado

A Minneapolis,

Minnesota

Duluth,

Minnesota

Entrance
Cooling and
Heating
Fraction
Multipliers

Timeframe That Best Aligns With Entrance Operating Hours

(Mcis

$\mathrm{M}_{\mathrm{CLG}}$

$\mathrm{M}_{\text {HTG }}$

$\mathrm{M}_{\mathrm{CLG}}$

$\mathrm{M}_{\mathrm{HTG}}$

$\mathrm{M}_{\mathrm{CLG}}$

$\mathrm{M}_{\text {HTG }}$

$\mathrm{M}_{\mathrm{CLG}}$

$\mathrm{M}_{\mathrm{HTG}}$

$\mathrm{M}_{\mathrm{CLG}}$

$\mathrm{M}_{\mathrm{HTC}}$

$\mathrm{M}_{\mathrm{CLG}}$

$\mathrm{M}_{\mathrm{HTC}}$

$\mathrm{M}_{\mathrm{CLG}}$

$\mathrm{M}_{\mathrm{HTC}}$

$\mathrm{M}_{\mathrm{CLG}}$

$\mathrm{M}_{\mathrm{HTG}}$

$\mathrm{M}_{\mathrm{CLG}}$

$\mathrm{M}_{\text {HTG }}$

$\mathrm{M}_{\mathrm{CLG}}$

$\mathrm{M}_{\mathrm{HTG}}$

1.02

\begin{tabular}{|c|c|}
\hline $\begin{array}{c}\text { All Day } \\
\text { (24-Hour } \\
\text { Period) }\end{array}$ & $\begin{array}{c}12: 00 \text { a.m. } \\
\text { to }\end{array}$ \\
$6: 00$ a.m. \\
\hline
\end{tabular}

6:00 a.m.

12:00 p.m.

\begin{tabular}{l|l|l} 
12:00 p.m. & $6: 00$ p.m. & $12: 00$ a.m.
\end{tabular}

\begin{tabular}{|l|l|l|l|l|}
\hline 1.00 & 1.00 & 1.00 & 1.00 & 1.00 \\
\hline 0.00 & 0.00 & 0.00 & 0.00 & 0.00 \\
\hline 0.29 & -0.11 & 0.26 & 1.00 & 0.00 \\
\hline 0.71 & 1.11 & 0.74 & 0.00 & 1.00 \\
\hline
\end{tabular}

0.01

0.99

0.99

$-0.03$

0.00

0.09

$-0.02$

1.03

1.00

0.91

1.02

0.23

$-0.02$

0.77

$-0.02$

1.02

0.18

$-0.02$

0.8

0.00

1.02

1.00

\begin{tabular}{l|l}
-0.02 \\
1.02
\end{tabular}

$-0.05$

1.02

$-0.02$

1.05

$-0.01$

1.02

1.01

$-0.02$

$-0.01$

\begin{tabular}{r|}
\hline .02 \\
-0.02
\end{tabular}

1.01

\begin{tabular}{|c|c|c|}
\hline-0.01 & 0.00 & -0.02 \\
\hline 1.01 & 1.00 & 1.02 \\
\hline-0.01 & -0.02 & -0.02 \\
\hline 1.01 & 1.02 & 1.02 \\
\hline
\end{tabular}

\begin{tabular}{l|l}
\hline 1.02 & 1.01 \\
\hline
\end{tabular}

Option C:

Leverage

Example 
According to your utility rate structure, estimate the costs of electricity for cooling $(\$ / \mathrm{kWh})$ and natural gas for heating (\$/therm) for your scenarios.

\section{Step 9 Estimate your cost savings potential}

Use Equation 1-7 and the estimated annual whole-building energy savings potential (value from Step 6) to estimate the energy cost savings potential.

$$
\mathrm{C}_{\text {savings }}=\mathrm{E}_{\text {savings }} \times\left(1000 / 3.41 \times \mathrm{M}_{\mathrm{CLG}} \times \mathrm{C}_{\mathrm{CLG}}+10 \times \mathrm{M}_{\mathrm{HTG}} \times \mathrm{C}_{\mathrm{HTG}}\right)
$$

where:

$$
\begin{array}{lll}
\mathrm{C}_{\text {savings }} & = & \text { annual energy cost savings potential }(\$) \\
\mathrm{E}_{\text {savings }} & = & \text { annual energy savings potential (MMBtu) } \\
\mathrm{M}_{\mathrm{CLG}} & = & \text { cooling fraction multiplier (dimensionless; see Table 1-4) } \\
\mathrm{C}_{\mathrm{CLG}} & = & \text { cost of electricity for cooling }(\$ / \mathrm{kWh}) \\
\mathrm{M}_{\mathrm{HTG}} & = & \text { heating fraction multiplier (dimensionless; see Table 1-4) } \\
\mathrm{C}_{\mathrm{HTG}} & = & \text { cost of natural gas for heating }(\$ / \text { therm) } \\
1000 / 3.41 & = & \text { conversion factor }(\mathrm{kWh} / \mathrm{MMBtu}) \\
10 & = & \text { conversion factor (therm/MMBtu) }
\end{array}
$$

\section{Step 10 Choose your next steps}

Use these initial estimates to decide whether to perform further site-specific analyses or engage vendors or contractors to price retrofit or new construction options. Appendix C provides suggestions about how to implement such a measure.

\footnotetext{
Op
} 


\section{Section 2}

\section{Vestibule Additions: Simulation-Based Method}

Overview

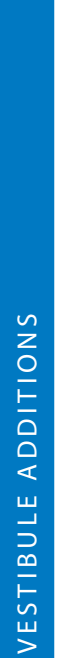

Option A:

Simplifiec

Method

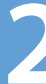

Option B:

Simulation

Method

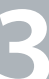

Option C:

Leverage

Example

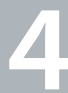

Option A:

Simplified

Method

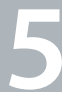

Option B:

Simulation

Method

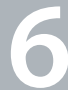

Option C:

Leverage

Example

References
This method applies to..

Building type: Free-standing retail buildings.

How the door is used: The door opens and closes as individuals pass through, as with a typical customer entrance door. (This excludes doors left open for extended periods.)

Door location: Any.

Compare to other methods in this guide...

Advantages: Freedom to enter site-specific information; capture system interactions.

Disadvantages: Requires more time and effort; may require external expertise.

\section{Introduction}

Vestibules can reduce infiltration at entrances where:

- Doors open and close as individuals pass through, rather than being left open for extended periods.

- Traffic passes frequently into conditioned spaces.

- Revolving doors are not practical.

Engineers can use whole-building energy simulations to estimate the energy and cost implications associated with vestibule additions. This section provides infiltration rates for a building with and without a vestibule for use in a whole-building energy simulation.

Engineers who have already used Section 1 to conduct an initial estimate can also use this section to conduct a site-specific analysis before implementing such a measure.

Appendix A provides details about how the steps and equations in this section were developed.

\section{Instructions}

Use the following steps to first estimate infiltration rates associated with your current door use scenario. Then proceed with whole-building energy simulation to complete the savings estimate.

\section{Step 1 Estimate an airflow coefficient based on door uses per hour}

Use Equations 2-1 through 2-4 to estimate the corresponding airflow coefficients for cases with and without a vestibule and cases with different door types and orientations. The door use rate (people per hour) is the average number of one-way trips through the door.

This value should be the annual average door use rate during entrance operating hours. Once you define the entrance operating hours, you need to use the same value for this parameter throughout the section.

If you do not know the actual door use rate, you can use the average number of retail sales transactions per hour to estimate it.

Example: During a typical week, a retail building has 3,500 transactions. There is one customer entrance, which is unlocked between 10:00 a.m. and 8:00 p.m. each day, for 70 entrance operating hours per week. This yields an average of 50 transactions per hour during these hours. The retailer assumes 50 people on average enter and exit the door per hour. This translates to 100 one-way trips per hour, or a door use rate of 100 people per hour. 
For a case without a vestibule:

$$
\mathrm{C}_{\mathrm{A}}=-0.0024 \times \mathrm{PPH}^{2}+3.813 \times \mathrm{PPH}-4.219
$$

For a vestibule with swinging doors:

$$
\mathrm{C}_{\mathrm{A}}=-0.0016 \times \mathrm{PPH}^{2}+2.722 \times \mathrm{PPH}-8.591
$$

For a vestibule with sliding doors, where the inner and outer doors are across from each other:

$$
\mathrm{C}_{\mathrm{A}}=-0.0013 \times \mathrm{PPH}^{2}+2.479 \times \mathrm{PPH}-7.518
$$

For a vestibule with sliding doors, where the outer doors are on the left or right side of the vestibule:

$$
\mathrm{C}_{\mathrm{A}}=-0.0012 \times \mathrm{PPH}^{2}+2.229 \times \mathrm{PPH}-6.637
$$

where:

$$
\begin{array}{lll}
\mathrm{C}_{\mathrm{A}} & = & \text { airflow coefficient }\left((\mathrm{cfm}) / \mathrm{ft}^{2} /(\mathrm{in} . \text { of water) }\right. \\
& \mathrm{PPH} & \\
\mathrm{PPH} & = & \text { annual average door use rate during entrance operating hours (people per hour) }
\end{array}
$$

The equations are second-order polynomial best fit lines that summarize selected airflow coefficients from Yuill (1996). See Appendix A for details.

\section{Step 2 Identify a pressure factor}

Choose your pressure factor, $\mathrm{R}_{\mathrm{P}}$, from Table 2-1. The methodology from the section titled "Air Leakage through Automatic Doors" in Chapter 16 of the ASHRAE Handbook of Fundamentals (ASHRAE 2009) was used to derive the values. You can adjust the conservatism or aggressiveness of your infiltration estimate by selecting different assumptions for average wind speed and local wind pressure coefficient, $C_{p}$. Appendix A provides methodology details.

Table 2-1. Pressure Factors $\left(R_{p}\right)$

\begin{tabular}{|c|c|c|}
\hline $\begin{array}{c}\text { Average Wind Speed } \\
\text { When Door Is in Use } \\
(\mathrm{mph})\end{array}$ & $\begin{array}{c}\text { Option 1: } \\
\text { Assume Wind Pressure Coefficient } \\
\text { With Moderate Impact on Infiltration } \\
\left(C_{\mathrm{p}}=0.45\right)\end{array}$ & $\begin{array}{c}\text { Option 2: } \\
\text { Assume Wind Pressure Coefficient } \\
\text { With Maximum Impact on Infiltration } \\
\left(C_{p}=0.70\right)\end{array}$ \\
\hline 5 & 0.07 & 0.09 \\
\hline 10 & 0.15 & 0.18 \\
\hline 15 & 0.22 & 0.28 \\
\hline 20 & 0.29 & 0.37 \\
\hline
\end{tabular}

\section{Step 3 Estimate your infiltration rates}

Apply your airflow coefficients, pressure factor, and door area in Equation 2-5 (ASHRAE 2009). Estimate your infiltration rates (cfm) for cases with and without a vestibule.

$$
C F M=C_{A} \times A \times R_{P}
$$

where:

$\begin{array}{lll}\mathrm{CFM} & = & \text { infiltration rate }(\mathrm{cfm}) \\ \mathrm{C}_{\mathrm{A}} & = & \text { airflow coefficient }\left((\mathrm{cfm}) / \mathrm{ft}^{2} /(\mathrm{in} . \text { of water })^{0.5}\right) \\ \mathrm{A} & = & \text { area of the door opening }\left(\mathrm{ft}^{2}\right) \\ \mathrm{R}_{\mathrm{P}} & = & \text { pressure factor }\left((\mathrm{in} . \text { of water })^{0.5}\right)\end{array}$




\section{Step $4 \quad$ Estimate your energy and cost savings potential}

Use the infiltration rates from Step 3 in your own energy simulations to estimate the impact of infiltration on energy consumption and cost for different scenarios. If you have a model of an existing building without a vestibule, you can model a vestibule addition by altering the infiltration rates associated with its entrance.

Overview

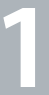

Option A:

Simplified

Method

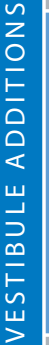

2

Option B:

Simulation

Method

5

Option C:

Leverage

Example

4

Option A:

Simplified

Method

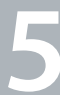

Option B:

Simulation

Method

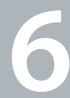

Option C:

Leverage

Example

References

\section{Step 5 Choose your next steps}

Use these initial estimates to decide whether to perform further site-specific analyses or engage vendors or contractors to price retrofit or new construction options. Appendix $C$ provides suggestions about how to implement such a measure. 


\section{Section 3}

\section{Vestibule Additions: Leveraging an Example Simulation for Supermarkets}

This method applies to.

Building type: Supermarket building of similar scale and operation as the example in this section. Results are provided for six climate zones.

How the door is used: The door opens and closes as individuals pass through, as with a typical customer entrance door. (This excludes doors left open for extended periods.)

Door location: Main entrance located at perimeter of conditioned sales area.

Compare to other methods in this guide..

Advantages: Relatively quick and easy; captures system interactions for a generic example.

Disadvantages: Little freedom to enter site-specific information or capture site-specific system interactions.

\section{Introduction}

NREL researchers used EnergyPlus (DOE 2011a) to evaluate the energy savings potential associated with vestibule additions in supermarket buildings. If your building is similar to the analyzed building, you can use the instructions in this section to estimate the energy and cost savings potential.

The baseline condition included a double door at the main entrance. Whole-building energy savings potential was estimated for two energy efficiency measures at this entrance:

- Adding a vestibule as an upgrade without modifying the HVAC equipment

- Adding a vestibule with a downsize in HVAC equipment as part of a deep retrofit.

The first measure is simpler; the second enables additional savings, including a reduction in fan energy.

Appendix A provides details about how the steps and equations in this section were developed.

\section{How the Instructions Were Developed for the Example Simulation}

The supermarket building model is $45,000 \mathrm{ft}^{2}$. It includes a total sales area of 25,000 $\mathrm{ft}^{2}$, refrigerated cases throughout the sales area, and HVAC equipment with humidity controls. The hours of typical door use are assumed to be 6:00 a.m. to 11:00 p.m. The model was adapted from the DOE Commercial Reference Building supermarket model for new construction (DOE 2010). Equipment efficiencies were based on the requirements in ASHRAE (2007).

Infiltration rates into the large sales area were modified for cases with and without a vestibule to quantify the effects of a vestibule addition. The entrance was assumed to be located at the perimeter of a sales area. The results show the estimated energy savings potential.

This analysis referenced Yuill (1996) and ASHRAE (2009). Equation A-3 was used to estimate infiltration rates as discussed in Appendix A. Assumptions included a 42- $\mathrm{ft}^{2}$ door area, representing a typical double door, and a pressure factor of 0.3 , applicable to buildings shorter than 50 feet (ASHRAE 2009). The average rate of door traffic was assumed to be 107 people per hour entering and exiting the building during occupied hours; this value was based on Yuill (1996), who monitored the door use of 59 retail buildings. The maximum rate of door traffic was assumed to be 180 people per hour; this value was derived from an examination of door schedules used in DOE (2010). A graph of this door use schedule is shown in Figure 3.

With these assumptions, the peak infiltration rate was estimated to be $4,300 \mathrm{cfm}$ for a door with a vestibule and 7,600 cfm without a vestibule. The average infiltration rates were estimated to be $2,700 \mathrm{cfm}$ and $4,700 \mathrm{cfm}$ for a door with and without a vestibule, respectively. Appendix A provides details about how airflow coefficients were estimated. 


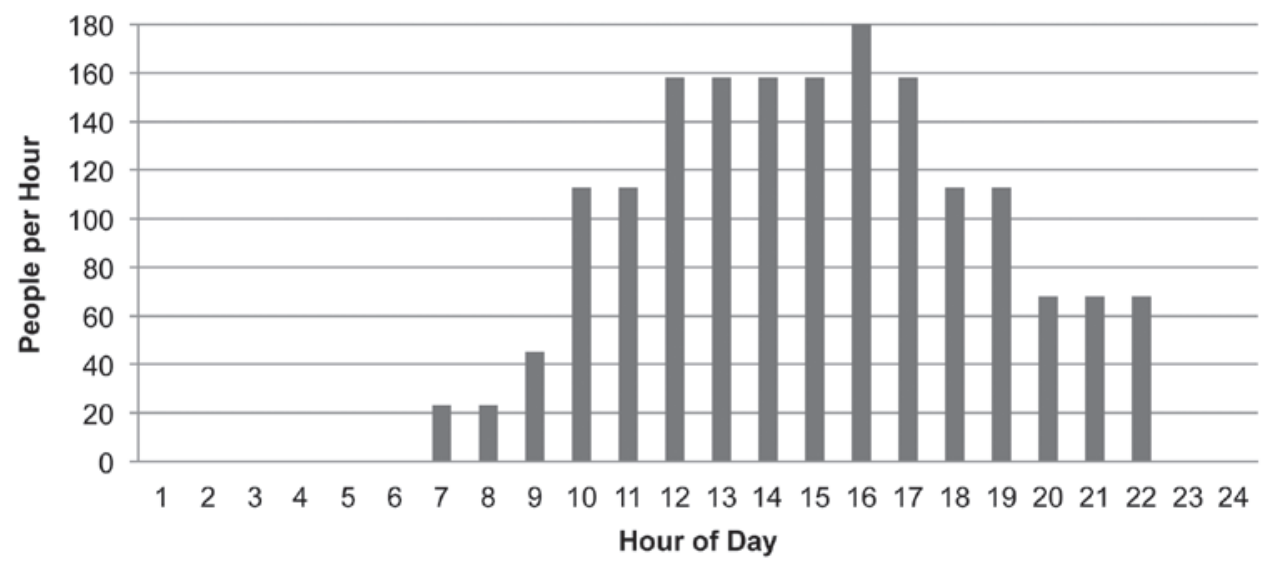

Figure 3. Rate of door traffic for each hour (adapted from DOE 2010)

\section{Instructions}

Use the following steps to estimate the savings potential associated with vestibule additions for your supermarket based on the analysis for a similar building. (A worksheet is provided in Appendix $\mathrm{F}$ to supplement this section.)

\section{Step $1 \quad$ Estimate your percent energy savings potential}

Use Table 3-1 to estimate the annual whole-building percent energy savings potential. These results were based on whole-building energy simulations of a generalized supermarket building. Choose the city with the most similar climate. (See Appendix D for a U.S. map of the DOE climate zones and representative cities.)

Option C:

Leverage

Example

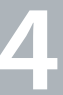

Option A:

Simplified

Method

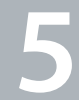

Option B:

Simulation

Method

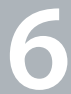

Option C:

Leverage

Table 3-1. Percent Energy Savings Potential for Supermarket Vestibule Additions

\begin{tabular}{|c|l|c|c|}
\hline & \multicolumn{2}{|c|}{ Location } & \multicolumn{2}{|c|}{$\begin{array}{c}\text { Annual Whole-Building Percent Energy Savings Potential for } \\
\text { Adding a Vestibule at One Double-Door Entrance }\end{array}$} \\
\hline $\begin{array}{c}\text { Climate } \\
\text { Zone }\end{array}$ & Reference City & $\begin{array}{c}\text { Adding a Vestibule Without } \\
\text { HVAC Modifications }\end{array}$ & $\begin{array}{c}\text { Adding a Vestibule With } \\
\text { HVAC Modifications }\end{array}$ \\
\hline 1A & Miami, Florida & $0.6 \%$ & $6.4 \%$ \\
\hline 3B & Las Vegas, Nevada & $1.4 \%$ & $1.7 \%$ \\
\hline 4C & Seattle, Washington & $2.6 \%$ & $2.6 \%$ \\
\hline 5A & Chicago, Illinois & $3.7 \%$ & $4.8 \%$ \\
\hline 5B & Boulder, Colorado & $2.3 \%$ & $2.5 \%$ \\
\hline 7 & Duluth, Minnesota & $4.1 \%$ & $4.4 \%$ \\
\hline
\end{tabular}

In humid regions such as Climate Zones $1 \mathrm{~A}$ and $5 \mathrm{~A}$, the difference between savings with and without HVAC modification tends to be greater than in drier regions such as Climate Zones $3 \mathrm{~B}$ and $5 \mathrm{~B}$. This is a consequence of differences in humidity and its effect on cooling energy. To simplify the comparison, the same rooftop unit system type and control strategy were used for all climate zones. No changes were made for active humidity control in the humid climates. In practice results may vary for different systems and humidity control strategies.

You should consider the following details as you review the results in Table 3-1. Energy savings depend on design assumptions such as system type and size. In locations with humidity issues, these assumptions significantly depend on the presence or absence of humidity control. In the warm-humid climate zones, for example, alternative system types (advanced direct expansion or desiccant systems) may be installed for dehumidification. If you pursue site-specific analyses in Step 6, you should adjust your assumptions accordingly. For new construction and deep retrofit cases, you should also consider reducing 
the system size if a reduction in infiltration reduces the HVAC load. The ability to downsize will depend on the magnitude of load reduction and the available sizes of HVAC equipment. Reducing the system size can enable additional savings, including a reduction in fan energy.

\section{Step 2 Estimate your energy savings potential}

Use Equation 3-1 to estimate the energy savings potential associated with a vestibule addition for your supermarket. Enter the annual whole-building percent energy savings potential identified from Step 1, as well as your store's measured annual whole-building energy use (MMBtu).

$$
\mathrm{E}_{\text {savings }}=\mathrm{E}_{\% \text { savings }} \times \mathrm{E}_{\text {total }}
$$

where:

$$
\begin{array}{lll}
\mathrm{E}_{\text {savings }} & = & \text { annual whole-building energy savings potential (MMBtu) } \\
\mathrm{E}_{\% \text { savings }} & = & \text { percent whole-building energy savings potential (\%) } \\
\mathrm{E}_{\text {total }} & = & \text { current measured annual whole-building energy use (MMBtu) }
\end{array}
$$

\section{Step 3 Select cooling and heating fraction multipliers}

Use Table 3-2 to identify the appropriate cooling and heating fraction multipliers that correspond to your location and the time that your door is typically in use. Choose the city with the most similar climate. (See Appendix D for a U.S. map of the DOE climate zones and representative cities.) The multipliers reflect the proportion of energy savings potential that is attributable to cooling or heating energy savings.

Assuming $\mathrm{E}_{\text {savings }}$ is positive in Step 2, a positive cooling (or heating) fraction multiplier in Table 3-2 indicates that the proposed strategy will reduce the cooling (or heating) load.

\begin{tabular}{|c|c|c|c|}
\hline \multicolumn{2}{|c|}{ Location } & \multirow{2}{*}{\multicolumn{2}{|c|}{$\begin{array}{l}\text { Entrance Cooling and Heating Fraction Multipliers } \\
\text { for Example Case } \\
\text { (With Entrance Operating Hours of 6:00 a.m. to 11:00 p.m. }\end{array}$}} \\
\hline Climate Zone & Reference City & & \\
\hline \multirow{2}{*}{$1 \mathrm{~A}$} & \multirow{2}{*}{ Miami, Florida } & $\mathrm{M}_{\mathrm{CLG}}$ & 1.00 \\
\hline & & $\mathrm{M}_{\mathrm{HTG}}$ & 0.00 \\
\hline \multirow{2}{*}{$3 B$} & \multirow{2}{*}{ Las Vegas, Nevada } & $\mathrm{M}_{\mathrm{CLG}}$ & 0.33 \\
\hline & & $\mathrm{M}_{\mathrm{HTG}}$ & 0.67 \\
\hline \multirow{2}{*}{$4 C$} & \multirow{2}{*}{ Seattle, Washington } & $\mathrm{M}_{\mathrm{CLG}}$ & -0.05 \\
\hline & & $\mathrm{M}_{\mathrm{HTG}}$ & 1.05 \\
\hline \multirow{2}{*}{$5 A$} & \multirow{2}{*}{ Chicago, Illinois } & $\mathrm{M}_{\mathrm{CLG}}$ & 0.00 \\
\hline & & $\mathrm{M}_{\mathrm{HTG}}$ & 1.00 \\
\hline \multirow{2}{*}{$5 B$} & \multirow{2}{*}{ Boulder, Colorado } & $\mathrm{M}_{\mathrm{CLG}}$ & -0.01 \\
\hline & & $\mathrm{M}_{\mathrm{HTG}}$ & 1.01 \\
\hline \multirow{2}{*}{7} & \multirow{2}{*}{ Duluth, Minnesota } & $\mathrm{M}_{\mathrm{CLG}}$ & -0.02 \\
\hline & & $\mathrm{M}_{\mathrm{HTG}}$ & 1.02 \\
\hline
\end{tabular}

The cooling fraction multiplier is occasionally a low negative number. In such cases, if $\mathrm{E}_{\text {savings }}$ is positive, the proposed strategy will increase the cooling load slightly, but the net whole-building energy consumption will still decrease.

Table 3-2. Entrance Cooling ( $\left.\mathrm{M}_{\mathrm{CLG}}\right)$ and Heating $\left(\mathrm{M}_{\mathrm{HTG}}\right)$ Fraction Multipliers for Vestibule Equations 
According to your utility rate structure, estimate the costs of electricity for cooling $(\$ / \mathrm{kWh})$ and natural gas for heating (\$/therm) for your scenarios.

\section{Step 5 Estimate your cost savings potential}

Use Equation 3-2 and the estimated annual whole-building energy savings potential (value from Step 2) to estimate the energy cost savings potential.

$$
\mathrm{C}_{\text {savings }}=\mathrm{E}_{\text {savings }} \times\left(1000 / 3.41 \times \mathrm{M}_{\mathrm{CLG}} \times \mathrm{C}_{\mathrm{CLG}}+10 \times \mathrm{M}_{\mathrm{HTG}} \times \mathrm{C}_{\mathrm{HTG}}\right)
$$

where:

$$
\begin{array}{lll}
\mathrm{C}_{\text {savings }} & = & \text { annual energy cost savings potential }(\$) \\
\mathrm{E}_{\text {savings }} & = & \text { annual energy savings potential (MMBtu) } \\
\mathrm{M}_{\mathrm{CLG}} & = & \text { cooling fraction multiplier (dimensionless; see Table 3-2) } \\
\mathrm{C}_{\mathrm{CLG}} & = & \text { cost of electricity for cooling }(\$ / \mathrm{kWh}) \\
\mathrm{M}_{\mathrm{HTG}} & = & \text { heating fraction multiplier (dimensionless; see Table 3-2) } \\
\mathrm{C}_{\mathrm{HTG}} & = & \text { cost of natural gas for heating }(\$ / \text { therm) } \\
1000 / 3.41 & = & \text { conversion factor }(\mathrm{kWh} / \mathrm{MMBtu}) \\
10 & = & \text { conversion factor (therm/MMBtu) }
\end{array}
$$

\section{Step 6 Choose your next steps}

Use these initial estimates to decide whether to perform further site-specific analyses or engage vendors or contractors to price retrofit or new construction options. Appendix $C$ provides suggestions about how to implement such a measure. 


\section{Section 4}

\section{Door Operation Changes: Simplified Method}

This method applies to..

Building type: Free-standing retail buildings. Equations are provided for 10 climate zones.

How the door is used: The door is left open for extended periods.

Door location: At the perimeter of a conditioned space.

Compare to other methods in this guide...

Advantages: Relatively quick and easy.

Disadvantages: Little freedom to enter site-specific information; does not capture system interactions.

\section{Introduction}

Door operation measures can include changes to when or how long the doors are open and changes to the effective door area. These measures may be applied to customer doors used for large item pickups, or to shipping and receiving doors used by retailers and their product distributors. This section provides a simplified method for estimating the energy and cost implications associated with alternative door operation.

Appendix B provides details about how the steps and equations in this section were developed.

\section{Instructions}

Use the following steps to estimate the energy and cost savings potential associated with alternative door operation. (A worksheet is provided in Appendix $\mathrm{G}$ to supplement this section.)

\section{Step 1 Select an area-normalized climate factor}

The area-normalized climate factor is a user input for Equation 4-1. This input accounts for variations in infiltration rate by climate, and is normalized by door area. Use Table 4-1 to select the appropriate factor for your location. Choose the city with the most similar climate. (See Appendix D for a U.S. map of the DOE climate zones and representative cities.)

Example: A retail building is located in Portland, Oregon. The building owner uses Appendix D and Table 4-1 to determine that Seattle, Washington, has the most similar climate as it is in the same climate zone. The owner selects the Climate Zone $4 C$ value, $F_{C A}=0.943$.

Table 4-1. Area-Normalized Climate Factors ( $\left.F_{C A}\right)$

\begin{tabular}{|c|c|c|}
\hline \multicolumn{2}{|c|}{ Location } & \multirow{2}{*}{$\begin{array}{l}\text { Area-Normalized Climate Factors, } \mathrm{F}_{\mathrm{C}} \\
\qquad\left(\mathrm{MMBtu} \cdot \mathrm{day} / \mathrm{h} / \mathrm{ft}^{2}\right)\end{array}$} \\
\hline Climate Zone & Reference City & \\
\hline $1 \mathrm{~A}$ & Miami, Florida & 0.063 \\
\hline $2 \mathrm{~A}$ & Houston, Texas & 0.271 \\
\hline $3 A$ & Atlanta, Georgia & 0.460 \\
\hline 3B & Las Vegas, Nevada & 0.361 \\
\hline $4 A$ & Baltimore, Maryland & 0.886 \\
\hline $4 C$ & Seattle, Washington & 0.943 \\
\hline $5 A$ & Chicago, Illinois & 1.573 \\
\hline $5 B$ & Boulder, Colorado & 1.121 \\
\hline $6 A$ & Minneapolis, Minnesota & 1.753 \\
\hline 7 & Duluth, Minnesota & 2.324 \\
\hline
\end{tabular}


If you know your door is typically left open within specific timeframes, you can use the time-of-day multipliers in Table 4-2 to adjust your estimate. Otherwise, assume a time-of-day multiplier of 1. The differences between the average outdoor and indoor temperatures for the specified timeframes were used to develop multipliers. Multipliers are provided for various climate zones. Choose the city with the most similar climate. (See Appendix D for a U.S. map of the DOE climate zones and representative cities.)

Example: A retail building in Portland, Oregon, has a door that is typically left open for two 30-minute delivery periods each day. Both usually occur between 5:00 a.m. and 8:00 a.m.

The building owner uses Appendix D and Table 4-2 and observes that Seattle, Washington, has the most similar climate as it is in the same climate zone. The owner also notes that the probable delivery window (5:00 a.m. to 8:00 a.m.) overlaps two timeframes in the table: 12:00 a.m. to 6:00 a.m., and 6:00 a.m. to 12:00 p.m. The time-of-day multipliers for these timeframes are 1.33 and 0.97, respectively.

Simplified

Option 1: The owner could calculate a simple average of 1.33 and 0.97 to yield $M_{T}=1.15$ for this case.

Option 2: The owner could calculate a weighted average. One third of the probable delivery window falls between 12:00 a.m. and 6:00 a.m.; two thirds falls between 6:00 a.m. and 12:00 p.m.; so the weighted average is $M_{T}=1.33 \times(1 / 3)+0.97 \times(2 / 3)=1.09$.

(If this example were continued into Step 4, $\mathrm{H}_{\mathrm{C}}$ in Equation 4-1 would be the total duration of all periods when the door is left open; with two half-hour delivery periods each day, $H_{c}$ would equal one hour per day.)

Table 4-2. Time-of-Day Multipliers $\left(\mathrm{M}_{\mathrm{T}}\right)$ for Door Operation Equations

\begin{tabular}{|c|c|c|c|c|c|}
\hline \multicolumn{2}{|r|}{ Location } & \multicolumn{4}{|c|}{ Timeframe Within Which Open-Door Periods Occur } \\
\hline $\begin{array}{l}\text { Climate } \\
\text { Zone }\end{array}$ & Reference City & $\begin{array}{c}\text { 12:00 a.m. to } \\
\text { 6:00 a.m. }\end{array}$ & $\begin{array}{c}\text { 6:00 a.m. to } \\
\text { 12:00 p.m. }\end{array}$ & $\begin{array}{l}12: 00 \text { p.m. to } \\
\text { 6:00 p.m. }\end{array}$ & $\begin{array}{l}\text { 6:00 p.m. to } \\
\text { 12:00 a.m. }\end{array}$ \\
\hline $1 A$ & Miami, Florida & 0.12 & 1.14 & 1.95 & 0.80 \\
\hline $2 \mathrm{~A}$ & Houston, Texas & 1.51 & 1.14 & 0.17 & 1.17 \\
\hline $3 A$ & Atlanta, Georgia & 1.47 & 1.06 & 0.58 & 0.88 \\
\hline 3B & Las Vegas, Nevada & 1.37 & 0.96 & 0.46 & 1.21 \\
\hline $4 \mathrm{~A}$ & Baltimore, Maryland & 1.31 & 0.98 & 0.65 & 1.06 \\
\hline $4 C$ & Seattle, Washington & 1.33 & 0.97 & 0.70 & 0.99 \\
\hline $5 A$ & Chicago, Illinois & 1.17 & 0.96 & 0.82 & 1.05 \\
\hline $5 B$ & Boulder, Colorado & 1.40 & 0.90 & 0.64 & 1.06 \\
\hline $6 A$ & Minneapolis, Minnesota & 1.16 & 1.00 & 0.85 & 0.99 \\
\hline 7 & Duluth, Minnesota & 1.16 & 1.00 & 0.81 & 1.03 \\
\hline
\end{tabular}

\section{Step 3 Identify your current and proposed strategies}

Identify your current door operation strategy and propose an alternative.

- Estimate the average hours per day the door is left open for your current strategy and for a proposed alternative strategy.

- Estimate the effective door area for your current strategy and for a proposed alternative strategy. The effective door area is defined as follows:

- If the door is partially open, as can be the case with an overhead door, the effective door area is the uncovered proportion of the doorway.

- If a door has an additional covering, such as a strip door curtain, its effective door area can be assumed to be equal to the percent infiltration reduction caused by the additional covering, multiplied by the total door area.

Consult manufacturers for estimates of how much their products will reduce infiltration rates for your scenarios. 
Example: A retailer has a 42-ft ${ }^{2}$ door with a plastic strip door curtain separating a conditioned space from the outdoor environment. The manufacturer claims the curtain will reduce infiltration rates by $X \%$ for this kind of application. The retailer could assume that the effective door area is $\mathrm{X} \% \times 42 \mathrm{ft}^{2}$.

- Energy efficiency strategies may include:

- Instruct delivery personnel to close doors more frequently. This may also affect delivery time, however, so you may first wish to estimate energy and delivery cost impacts.

- Install sensor-operated quick-opening doors. This may reduce the time doors are open and mitigate delivery cost impacts.

- Employ partial door opening strategies. You may want to use a lower default overhead door height for most deliveries and switch to the maximum door height for larger deliveries. Another strategy is to install curtains to reduce the effective door area.

\section{Step $4 \quad$ Estimate your energy savings potential}

Use Equation 4-1 to estimate the whole-building energy savings potential associated with your alternative door operation. The equation is written such that when $\mathrm{E}_{\text {savings }}$ is positive, the proposed strategy saves energy over the current strategy.

$$
E_{\text {savings }}=F_{C A} \times M_{T} \times\left(A_{C} \times H_{C}-A_{P} \times H_{P}\right)
$$

where:

$\begin{array}{lll}\mathrm{E}_{\text {savings }} & = & \text { annual energy savings potential (MMBtu) } \\ \mathrm{F}_{\mathrm{CA}} & = & \text { area-normalized climate factor (MMBtu·day } / \mathrm{h} / \mathrm{ft}^{2} \text {; see Table 4-1) } \\ \mathrm{M}_{\mathrm{T}} & = & \text { time-of-day multiplier (dimensionless; see Table 4-2) } \\ \mathrm{A}_{\mathrm{C}} & = & \text { effective door area for current strategy }\left(\mathrm{ft}^{2}\right) \\ \mathrm{H}_{\mathrm{C}} & = & \text { hours per day door is left open for current strategy }(\mathrm{h} / \mathrm{day}) \\ \mathrm{A}_{\mathrm{P}} & = & \text { effective door area for proposed strategy }\left(\mathrm{ft}^{2}\right) \\ \mathrm{H}_{\mathrm{P}} & = & \text { hours per day door is left open for proposed strategy }(\mathrm{h} / \mathrm{day})\end{array}$

\section{Step 5 Select cooling and heating fraction multipliers}

Use Table 4-3 to identify the appropriate cooling and heating fraction multipliers that correspond to your location and the time your door is typically in use. Choose the city with the most similar climate. (See Appendix D for a U.S. map of the DOE climate zones and representative cities.) The multipliers reflect the proportion of energy savings potential that is attributable to cooling or heating energy savings.

Assuming $\mathrm{E}_{\text {savings }}$ is positive in Step 4, a positive cooling (or heating) fraction multiplier in Table 4-3 indicates the proposed strategy will reduce the cooling (or heating) load.

The cooling fraction multiplier is occasionally a low negative number. In such cases, if $\mathrm{E}_{\text {savings }}$ is positive, the proposed strategy will increase the cooling load slightly, but the net whole-building energy consumption will still decrease.

As in the example from Step 2, if the average entrance operating hours overlap multiple timeframes, a cooling fraction multiplier and a heating fraction multiplier can be estimated in Step 5 by performing either a simple average or a weighted average of values from applicable timeframes in Table 4-3. 
Table 4-3. Entrance Cooling ( $\left.\mathrm{M}_{\mathrm{CLG}}\right)$ and Heating $\left(\mathrm{M}_{\mathrm{HTG}}\right)$ Fraction Multipliers for Door Operation Equations

Overview

1

Option A:

Simplified

Method

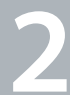

Option B:

Simulation

Method

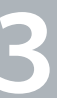

Option C:

Leverage

Example

4

Option A:

Simplified

Method

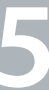

Option B:

Simulation

Method

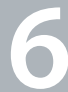

Option C:

Leverage

Example

\begin{tabular}{|c|c|c|c|c|c|c|c|}
\hline \multicolumn{2}{|c|}{ Location } & \multirow{2}{*}{$\begin{array}{l}\text { Entrance } \\
\text { Cooling and } \\
\text { Heating } \\
\text { Fraction } \\
\text { Multipliers }\end{array}$} & \multicolumn{5}{|c|}{ Timeframe Within Which Open-Door Periods Occur } \\
\hline $\begin{array}{l}\text { Climate } \\
\text { Zone }\end{array}$ & Reference City & & $\begin{array}{l}\text { All Day } \\
\text { (24-Hour } \\
\text { Period) }\end{array}$ & $\begin{array}{c}\text { 12:00 a.m. } \\
\text { to } \\
6: 00 \text { a.m. }\end{array}$ & $\begin{array}{c}\text { 6:00 a.m. } \\
\text { to } \\
\text { 12:00 p.m. }\end{array}$ & $\begin{array}{c}\text { 12:00 p.m. } \\
\text { to } \\
\text { 6:00 p.m. }\end{array}$ & $\begin{array}{c}\text { 6:00 p.m. } \\
\text { to } \\
\text { 12:00 a.m. }\end{array}$ \\
\hline \multirow{2}{*}{$1 \mathrm{~A}$} & \multirow{2}{*}{$\begin{array}{l}\text { Miami, } \\
\text { Florida }\end{array}$} & $\mathrm{M}_{\mathrm{CLG}}$ & 1.00 & 1.00 & 1.00 & 1.00 & 1.00 \\
\hline & & $\mathrm{M}_{\mathrm{HTG}}$ & 0.00 & 0.00 & 0.00 & 0.00 & 0.00 \\
\hline \multirow{2}{*}{$2 A$} & \multirow{2}{*}{ Houston, Texas } & $\mathrm{M}_{\mathrm{CLG}}$ & 0.27 & -0.12 & 0.23 & 1.00 & -0.03 \\
\hline & & $\mathrm{M}_{\mathrm{HTG}}$ & 0.73 & 1.12 & 0.77 & 0.00 & 1.03 \\
\hline \multirow{2}{*}{$3 A$} & \multirow{2}{*}{$\begin{array}{l}\text { Atlanta, } \\
\text { Georgia }\end{array}$} & $\mathrm{M}_{\mathrm{CLG}}$ & 0.02 & -0.04 & 0.00 & 0.15 & -0.04 \\
\hline & & $\mathrm{M}_{\mathrm{HTG}}$ & 0.98 & 1.04 & 1.00 & 0.85 & 1.04 \\
\hline \multirow{2}{*}{$3 B$} & \multirow{2}{*}{$\begin{array}{l}\text { Las Vegas, } \\
\text { Nevada }\end{array}$} & $\mathrm{M}_{\mathrm{CLG}}$ & 0.28 & -0.03 & 0.26 & 0.76 & 0.12 \\
\hline & & $\mathrm{M}_{\mathrm{HTG}}$ & 0.72 & 1.03 & 0.74 & 0.24 & 0.88 \\
\hline \multirow{2}{*}{$4 \mathrm{~A}$} & \multirow{2}{*}{$\begin{array}{l}\text { Baltimore, } \\
\text { Maryland }\end{array}$} & $\mathrm{M}_{\mathrm{CLG}}$ & -0.01 & -0.02 & -0.01 & 0.00 & -0.02 \\
\hline & & $\mathrm{M}_{\mathrm{HTG}}$ & 1.01 & 1.02 & 1.01 & 1.00 & 1.02 \\
\hline \multirow{2}{*}{$4 C$} & \multirow{2}{*}{$\begin{array}{l}\text { Seattle, } \\
\text { Washington }\end{array}$} & $\mathrm{M}_{\mathrm{CLG}}$ & -0.04 & -0.02 & -0.05 & -0.05 & -0.05 \\
\hline & & $\mathrm{M}_{\mathrm{HTG}}$ & 1.04 & 1.02 & 1.05 & 1.05 & 1.05 \\
\hline \multirow{2}{*}{$5 A$} & \multirow{2}{*}{$\begin{array}{l}\text { Chicago, } \\
\text { Illinois }\end{array}$} & $\mathrm{M}_{\mathrm{CLG}}$ & -0.01 & -0.02 & -0.01 & 0.00 & -0.01 \\
\hline & & $\mathrm{M}_{\mathrm{HTG}}$ & 1.01 & 1.02 & 1.01 & 1.00 & 1.01 \\
\hline \multirow{2}{*}{$5 B$} & \multirow{2}{*}{$\begin{array}{l}\text { Boulder, } \\
\text { Colorado }\end{array}$} & $\mathrm{M}_{\mathrm{CLG}}$ & -0.01 & -0.01 & -0.01 & 0.00 & -0.02 \\
\hline & & $\mathrm{M}_{\mathrm{HTG}}$ & 1.01 & 1.01 & 1.01 & 1.00 & 1.02 \\
\hline \multirow{2}{*}{$6 \mathrm{~A}$} & \multirow{2}{*}{$\begin{array}{l}\text { Minneapolis, } \\
\text { Minnesota }\end{array}$} & $\mathrm{M}_{\mathrm{CLG}}$ & -0.01 & -0.02 & -0.01 & 0.00 & -0.02 \\
\hline & & $\mathrm{M}_{\mathrm{HTG}}$ & 1.01 & 1.02 & 1.01 & 1.00 & 1.02 \\
\hline \multirow{2}{*}{7} & \multirow{2}{*}{$\begin{array}{l}\text { Duluth, } \\
\text { Minnesota }\end{array}$} & $\mathrm{M}_{\mathrm{CLG}}$ & -0.01 & -0.01 & -0.01 & -0.02 & -0.01 \\
\hline & & $M_{H T G}$ & 1.01 & 1.01 & 1.01 & 1.02 & 1.01 \\
\hline
\end{tabular}

\section{Step 6 Estimate the costs associated with cooling and heating}

According to your utility rate structure, estimate the costs of electricity for cooling $(\$ / \mathrm{kWh})$ and natural gas for heating $(\$ /$ therm) for your scenarios. 


\section{Step $7 \quad$ Estimate your cost savings potential}

Use Equation 4-2 and the estimated annual whole-building energy savings potential (value from Step 4) to estimate the energy cost savings potential.

$$
\mathrm{C}_{\text {savings }}=\mathrm{E}_{\text {savings }} \times\left(1000 / 3.41 \times \mathrm{M}_{\mathrm{CLG}} \times \mathrm{C}_{\mathrm{CLG}}+10 \times \mathrm{M}_{\mathrm{HTG}} \times \mathrm{C}_{\mathrm{HTG}}\right)
$$

where:

$\begin{array}{lll}\mathrm{C}_{\text {savings }} & = & \text { annual energy cost savings potential }(\$) \\ \mathrm{E}_{\text {savings }} & = & \text { annual energy savings potential }(\mathrm{MMBtu}) \\ \mathrm{M}_{\mathrm{CLG}} & = & \text { cooling fraction multiplier (dimensionless; see Table 4-3) } \\ \mathrm{C}_{\mathrm{CLG}} & = & \text { cost of electricity for cooling }(\$ / \mathrm{kWh}) \\ \mathrm{M}_{\mathrm{HTG}} & = & \text { heating fraction multiplier (dimensionless; see Table 4-3) } \\ \mathrm{C}_{\mathrm{HTG}} & = & \text { cost of natural gas for heating }(\$ / \text { therm) } \\ 1000 / 3.41 & = & \text { conversion factor }(\mathrm{kWh} / \mathrm{MMBtu}) \\ 10 & = & \text { conversion factor (therm/MMBtu) }\end{array}$

\section{Step $8 \quad$ Choose your next steps}

Use these initial estimates to decide whether to perform further site-specific analyses, engage vendors or contractors to price retrofit or new construction options, or test door operation changes. Appendix C provides suggestions about how to implement such a measure. 


\section{Section 5}

Door Operation Changes: Simulation-Based Method

Overview

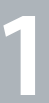

Option A:

Simplified

Method

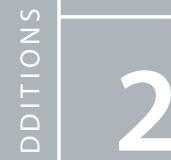

Option B:

Simulation

Method

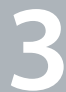

Option C

Leverage

Example

Option B:

Simulation

Method

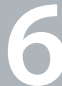

Option C:

Leverage

Example
This method applies to...

Building type: Free-standing retail buildings.

How the door is used: The door is left open for extended periods.

Door location: Any.

Compare to other methods in this guide...

Advantages: Freedom to enter site-specific information; captures system interactions.

Disadvantages: Requires more time and effort; may require external expertise.

\section{Introduction}

Door operation measures can include changes to when or how long the doors are open and changes to the effective door area. These measures may be applied to customer doors used for large item pickups, or to shipping and receiving doors used by retailers and their product distributors.

Engineers can use a simulation-based approach to conduct their first assessment of an alternative door operation measure. Engineers who have already used Section 4 to conduct an initial estimate can also use this section to conduct a site-specific analysis before implementing such a measure.

Appendix B provides details about how the steps and equations in this section were developed.

\section{Instructions}

Use the following steps to estimate the savings potential associated with alternative door operation.

\section{Step 1 Estimate your infiltration rates}

An NREL whole-building energy simulation analysis examined infiltration impacts for effective door areas up to $230 \mathrm{ft}^{2}$. The relationship between infiltration rate and effective door area was fairly linear in the 0 to $230-\mathrm{ft}^{2}$ range that was examined. The 230- $\mathrm{ft}^{2}$ upper limit was based on Retailer Energy Alliance member feedback about the size of their largest customer doors.

Use Table 5-1 or Equation 5-1, and choose the table values for the city with the most similar climate to estimate your monthly or annual average infiltration rates (see Appendix D for a U.S. map of the DOE climate zones and representative cities):

- If you have a large door with an effective area near $230 \mathrm{ft}^{2}$, use Table 5-1.

- To estimate the infiltration rates of effective door areas smaller than $230 \mathrm{ft}^{2}$, use Equation $5-1$. 


\begin{tabular}{|c|c|c|c|c|c|c|}
\hline \multirow[b]{2}{*}{ Month } & \multicolumn{6}{|c|}{ Location } \\
\hline & $\begin{array}{c}1 \mathrm{~A} \\
\text { (Miami, } \\
\text { Florida) }\end{array}$ & $\begin{array}{c}\text { 3B } \\
\text { (Las Vegas, } \\
\text { Nevada) }\end{array}$ & $\begin{array}{c}4 C \\
\text { (Seattle, } \\
\text { Washington) }\end{array}$ & $\begin{array}{c}5 A \\
\text { (Chicago, } \\
\text { Illinois) }\end{array}$ & $\begin{array}{c}\text { 5B } \\
\text { (Boulder, } \\
\text { Colorado) }\end{array}$ & $\begin{array}{c}7 \\
\text { (Duluth, } \\
\text { Minnesota) }\end{array}$ \\
\hline January & 31,200 & 19,800 & 26,200 & 33,900 & 25,300 & 36,400 \\
\hline February & 33,400 & 21,400 & 23,100 & 40,400 & 29,400 & 38,000 \\
\hline March & 36,300 & 26,000 & 27,700 & 35,800 & 28,600 & 39,600 \\
\hline April & 39,600 & 40,300 & 39,100 & 41,700 & 30,500 & 34,100 \\
\hline May & 32,000 & 27,700 & 29,500 & 29,500 & 27,400 & 31,500 \\
\hline June & 24,500 & 39,200 & 25,000 & 35,700 & 27,200 & 29,900 \\
\hline July & 29,900 & 29,900 & 26,500 & 26,900 & 22,100 & 27,600 \\
\hline August & 29,600 & 30,100 & 26,200 & 30,700 & 20,100 & 23,500 \\
\hline September & 22,900 & 20,100 & 28,900 & 27,500 & 23,100 & 32,500 \\
\hline October & 25,200 & 28,100 & 26,800 & 41,100 & 18,300 & 36,300 \\
\hline November & 36,900 & 19,500 & 34,300 & 33,000 & 26,600 & 35,200 \\
\hline December & 35,600 & 16,300 & 21,400 & 35,100 & 26,200 & 30,600 \\
\hline Annual average & 31,400 & 26,500 & 27,900 & 34,300 & 25,400 & 32,900 \\
\hline
\end{tabular}

The equation for estimating infiltration rates of effective door areas smaller than $230 \mathrm{ft}^{2}$ is:

$$
\mathrm{CFM}=(\mathrm{A} / 230) \times \mathrm{CFM}_{230}
$$

where:

$$
\begin{array}{lll}
\text { CFM } & = & \text { infiltration rate }(\mathrm{cfm}) \\
\mathrm{A} & = & \text { effective door area }\left(\mathrm{ft}^{2}\right) \\
230 & = & \text { reference effective door area used to produce Table } 5-1 \text { values }\left(\mathrm{ft}^{2}\right) \\
\mathrm{CFM}_{230} & = & \text { infiltration rate from Table } 5-1(\mathrm{cfm})
\end{array}
$$

Note that the usability of Equation 5-1 for doors larger than $230 \mathrm{ft}^{2}$ was not assessed.

\section{Step 2 Estimate your energy and cost savings potential}

Use the infiltration rates determined in Step 1 in your own energy models to estimate the impact of infiltration on energy consumption and cost for different scenarios. One way to do this is to create a separate infiltration object that represents infiltration through an open door. Use other infiltration objects to represent infiltration that occurs when the door is shut. This could include infiltration through imperfections in the door construction, as well as other elements of the building envelope, such as walls, roofs, and windows.

For the door's infiltration object, you may need to define an infiltration schedule that specifies infiltration rates for multiple times of day. These schedules can be used to represent when doors are open or closed. For times when the door is open, use the infiltration rate from Step 1 as your input. For times when the door is closed, set the infiltration rate to zero (for the door infiltration object only). 
Once you have defined an infiltration object and schedule for your baseline scenario, you can adjust your inputs to represent alternative scenarios. Changes to inputs for the alternative scenarios may include:

- Change the times when the infiltration rate is zero or nonzero to represent a modification to when or how long the doors are open.

- Change the magnitude of the nonzero infiltration rates to represent a change in the effective door area.

Alternatively, some simulation applications may allow you to calculate infiltration rates from other user inputs. For example, the EnergyPlus infiltration object allows you to specify such inputs as the neutral pressure of the building, the door area, and the door orientation. For more details, consult the user documentation for your whole-building simulation application.

\section{Step 3 Choose your next steps}

Simplified

Use these initial estimates to decide whether to perform further site-specific analyses, engage vendors or contractors to price retrofit or new construction options, or test door operation changes in your stores. Appendix C provides suggestions about how to implement such a measure.

Option C:

Leverage

Example 


\section{Section 6}

Door Operation Changes: Leveraging an Example Simulation for Large Retail Buildings

This method applies to...

Building type: Large retail building of similar scale, use, and operation as the example in this section. Results are provided for six climate zones.

How the door is used: The door is left open for extended periods.

Door location: An entrance located at the perimeter of a conditioned sales area.

Compare to other methods in this guide...

Advantages: Relatively quick and easy; captures system interactions for a generic example.

Disadvantages: Little freedom to enter site-specific information or capture site-specific system interactions.

\section{Introduction}

Door operation measures can include changes to when or how long the doors are open and changes to the effective door area. These measures may be applied to customer doors used for large item pickups, or to shipping and receiving doors used by retailers and their product distributors.

NREL researchers used EnergyPlus (DOE 2011a) to evaluate the energy savings potential associated with door operation changes in large retail buildings. Various alternative strategies were simulated for a bay door located at the perimeter of a sales area. If your building is similar to the analyzed building, you can use the instructions in this section to adapt the example results and estimate the energy and cost savings potential for your scenarios.

Appendix B provides details about how the steps and equations in this section were developed.

\section{How the Instructions Were Developed for the Example Simulation}

The large retail building model is $110,000 \mathrm{ft}^{2}$. It includes a total sales area of $87,500 \mathrm{ft}^{2}$ with no refrigerated cases. This model was created by modifying whole-building energy models developed at NREL (see the Acknowledgments section). In this example, the building model was designed to represent a home improvement store with a bay door for customers purchasing large items. Equipment efficiencies were based on the requirements in ASHRAE (2007).

Feedback from Retailer Energy Alliance members suggested that such buildings do not frequently include active humidity controls, but that occupants may manually override default thermostat settings if necessary to maintain comfort. To simulate this effect, the building model lowered the thermostat set point from $74^{\circ} \mathrm{F}$ to $72^{\circ} \mathrm{F}$ when the dew point temperature exceeded $57^{\circ} \mathrm{F}$. The temperature set point was reset to $74^{\circ} \mathrm{F}$ each day. A dew point of $57^{\circ} \mathrm{F}$ represented a threshold above which people start to notice discomfort.

Table 6-1 provides a summary of estimated percent energy increase for an example case. This depicts the energy impact of leaving a $230 \mathrm{ft}^{2}$ door open for an average of 3 hours per day. The results are provided for all climate zones that were analyzed.

Table 6-1. Whole-Building Energy Increase for Example Door Condition

\begin{tabular}{|c|c|c|}
\hline \multicolumn{2}{|c|}{ Location } & \multirow{2}{*}{$\begin{array}{c}\text { Whole-Building Energy Percent Increase } \\
\text { Baseline: Door Is Always Closed } \\
\text { Alternative: } 230-\mathrm{ft}^{2} \text { Bay Door Is Open } 3 \text { Hours/Day }\end{array}$} \\
\hline Climate Zone & Reference City & \\
\hline $1 \mathrm{~A}$ & Miami, Florida & $2.0 \%$ \\
\hline $3 B$ & Las Vegas, Nevada & $1.9 \%$ \\
\hline $4 C$ & Seattle, Washington & $5.3 \%$ \\
\hline $5 A$ & Chicago, Illinois & $7.8 \%$ \\
\hline $5 B$ & Boulder, Colorado & $4.0 \%$ \\
\hline 7 & Duluth, Minnesota & $9.3 \%$ \\
\hline
\end{tabular}




\section{Instructions}

Use the following steps to estimate the energy and cost savings potential associated with alternative door operation for large retail buildings (without refrigerated cases). (A worksheet is provided in Appendix $\mathrm{H}$ to supplement this section.)

\section{Step 1 Select an energy savings factor}

The energy savings factor is a user input that will be used in Equation 6-1. This input accounts for variations in energy savings potential for each climate. Use Table 6-2 to select the appropriate climate factor for your location. Choose the city with the most similar climate. (See Appendix D for a U.S. map of the DOE climate zones and representative cities.)

Option A:

Simplified

Method

Table 6-2. Energy Savings Factor ( $\left.\mathrm{F}_{\mathrm{ES}}\right)$

\begin{tabular}{|c|c|c|}
\hline \multicolumn{2}{|c|}{ Location } & \multirow{2}{*}{$\begin{array}{l}\text { Energy Savings Factor, } F_{\mathrm{ES}} \\
\left(\mathrm{MMBtu} \cdot \mathrm{day} / \mathrm{h} / \mathrm{ft}^{2}\right)\end{array}$} \\
\hline Climate Zone & Reference City & \\
\hline $1 \mathrm{~A}$ & Miami, Florida & 0.267 \\
\hline 3B & Las Vegas, Nevada & 0.233 \\
\hline $4 C$ & Seattle, Washington & 0.586 \\
\hline $5 A$ & Chicago, Illinois & 1.177 \\
\hline 5B & Boulder, Colorado & 0.512 \\
\hline 7 & Duluth, Minnesota & 1.764 \\
\hline
\end{tabular}

\section{Step 2 Identify your current and proposed strategies}

Identify your current door operation strategy and propose an alternative.

- Estimate the average hours per day the door is left open for your current strategy and for a proposed alternative strategy.

- Estimate the effective door area for your current strategy and for a proposed alternative strategy. The effective door area is defined as follows:

- If the door is partially open, as can be the case with an overhead door, the effective door area is the uncovered proportion of the doorway.

- If a door has an additional covering, such as a strip door curtain, its effective door area can be assumed to be equal to the percent infiltration reduction caused by the additional covering, multiplied by the total door area.

Consult manufacturers for estimates of how much their products will reduce infiltration rates for your scenarios.

Example: A retailer has a 42-ft ${ }^{2}$ door with a plastic strip door curtain separating a conditioned space from the outdoor environment. The manufacturer claims the curtain will reduce infiltration rates by X\% for this kind of application. The retailer could assume that the effective door area is $X \% \times 42 \mathrm{ft}^{2}$.

- Energy efficiency strategies may include:

- Instruct delivery personnel to close doors more frequently. This may also affect delivery time, however, so you may first wish to estimate energy and delivery cost impacts.

- Install sensor-operated quick-opening doors. This may reduce the time doors are open and mitigate delivery cost impacts.

- Employ partial door opening strategies. You may want to use a lower default overhead door height for most deliveries and switch to the maximum door height for larger deliveries. Another strategy is to install curtains to reduce the effective door area. 
Use Equation 6-1 to estimate the whole-building energy savings potential associated with alternative door operation. The equation is written such that when $\mathrm{E}_{\text {savings }}$ is positive, the proposed strategy saves energy over the current strategy.

$$
E_{\text {savings }}=F_{E S} \times\left(A_{C} \times H_{C}-A_{P} \times H_{P}\right)
$$

where:

$\begin{array}{lll}\mathrm{E}_{\mathrm{savings}} & = & \text { annual whole-building energy savings potential (MMBtu) } \\ \mathrm{F}_{\mathrm{ES}} & = & \left.\text { energy savings factor }\left(\mathrm{MMBtu} \cdot \mathrm{day} / \mathrm{h} / \mathrm{ft}^{2}\right) ; \text { see Table } 6-2\right) \\ \mathrm{A}_{\mathrm{C}} & = & \text { effective door area for current strategy }\left(\mathrm{ft}^{2}\right) \\ \mathrm{H}_{\mathrm{C}} & = & \text { hours per day door is left open for current strategy }(\mathrm{h} / \mathrm{day}) \\ \mathrm{A}_{\mathrm{P}} & = & \text { effective door area for proposed strategy }\left(\mathrm{ft}^{2}\right) \\ \mathrm{H}_{\mathrm{P}} & = & \text { hours per day door is left open for proposed strategy }(\mathrm{h} / \text { day })\end{array}$

\section{Step 4 Select cooling and heating fraction multipliers}

Use Table 6-3 to identify the appropriate cooling and heating fraction multipliers that correspond to your location. Choose the city with the most similar climate. (See Appendix D for a U.S. map of the DOE climate zones and representative cities.) The multipliers reflect the proportion of energy savings potential that is attributable to cooling or heating energy savings.

Assuming $\mathrm{E}_{\text {savings }}$ is positive in Step 4, a positive cooling (or heating) fraction multiplier in Table 6-3 indicates that the proposed strategy will reduce the cooling (or heating) load.

The cooling fraction multiplier is occasionally a low negative number. In such cases, if $\mathrm{E}_{\text {savings }}$ is positive, the proposed strategy will increase the cooling load slightly, but the net whole-building energy consumption will still decrease.

Table 6-3. Entrance Cooling $\left(\mathrm{M}_{\mathrm{CLG}}\right)$ and Heating $\left(\mathrm{M}_{\mathrm{HTG}}\right)$ Fraction Multipliers for Door Operation Equations

\begin{tabular}{|c|c|c|c|}
\hline \multicolumn{2}{|c|}{ Location } & \multirow{2}{*}{\multicolumn{2}{|c|}{$\begin{array}{l}\text { Entrance Cooling and Heating Fraction } \\
\text { Multipliers for Example Case } \\
\text { (With Door Left Open Between 1:00 p.m. and 4:00 p.m.) }\end{array}$}} \\
\hline Climate Zone & Reference City & & \\
\hline \multirow{2}{*}{$1 \mathrm{~A}$} & \multirow{2}{*}{ Miami, Florida } & $\mathrm{M}_{\mathrm{CLG}}$ & 1.00 \\
\hline & & $\mathrm{M}_{\mathrm{HTG}}$ & 0.00 \\
\hline \multirow{2}{*}{$3 B$} & \multirow{2}{*}{ Las Vegas, Nevada } & $\mathrm{M}_{\mathrm{CLG}}$ & 1.00 \\
\hline & & $\mathrm{M}_{\mathrm{HTG}}$ & 0.00 \\
\hline \multirow{2}{*}{$4 C$} & \multirow{2}{*}{ Seattle, Washington } & $\mathrm{M}_{\mathrm{CLG}}$ & -0.06 \\
\hline & & $\mathrm{M}_{\mathrm{HTG}}$ & 1.06 \\
\hline \multirow{2}{*}{$5 A$} & \multirow{2}{*}{ Chicago, Illinois } & $\mathrm{M}_{\mathrm{CLG}}$ & 0.01 \\
\hline & & $\mathrm{M}_{\mathrm{HTG}}$ & 0.99 \\
\hline \multirow{2}{*}{$5 B$} & \multirow{2}{*}{ Boulder, Colorado } & $\mathrm{M}_{\mathrm{CLG}}$ & 0.01 \\
\hline & & $\mathrm{M}_{\mathrm{HTG}}$ & 0.99 \\
\hline \multirow{2}{*}{7} & \multirow{2}{*}{ Duluth, Minnesota } & $\mathrm{M}_{\mathrm{CLG}}$ & -0.02 \\
\hline & & $\mathrm{M}_{\mathrm{HTG}}$ & 1.02 \\
\hline
\end{tabular}

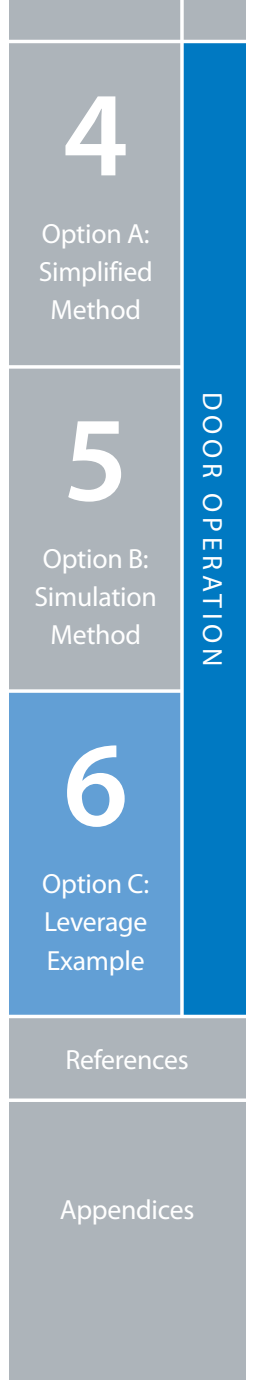




\section{Step 5 Estimate your costs associated with cooling and heating}

According to your utility rate structure, estimate the costs of electricity for cooling $(\$ / \mathrm{kWh})$ and natural gas for heating (\$/therm) for your scenarios.

Overview

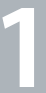

Option A:

Simplified

Method

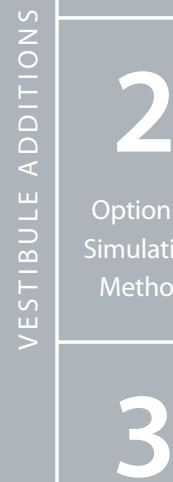

Option C.

Leverage

Example

4

Option A:

Simplified

Method

Option B:

Simulation

Method

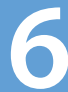

Option C:

Leverage

Example

\section{Step 6 Estimate your cost savings potential}

Use Equation 6-2 and the estimated annual whole-building energy savings potential (value from Step 3) to estimate the energy cost savings potential.

$$
\mathrm{C}_{\text {savings }}=\mathrm{E}_{\text {savings }} \times\left(1000 / 3.41 \times \mathrm{M}_{\mathrm{CLG}} \times \mathrm{C}_{\mathrm{CLG}}+10 \times \mathrm{M}_{\mathrm{HTG}} \times \mathrm{C}_{\mathrm{HTG}}\right)
$$

where:

$\begin{array}{lll}\mathrm{C}_{\text {savings }} & = & \text { annual energy cost savings potential }(\$) \\ \mathrm{E}_{\text {savings }} & = & \text { annual energy savings potential (MMBtu) } \\ \mathrm{M}_{\mathrm{CLG}} & = & \text { cooling fraction multiplier (dimensionless; see Table 6-3) } \\ \mathrm{C}_{\mathrm{CLG}} & = & \text { cost of electricity for cooling }(\$ / \mathrm{kWh}) \\ \mathrm{M}_{\mathrm{HTG}} & = & \text { heating fraction multiplier (dimensionless; see Table 6-3) } \\ \mathrm{C}_{\mathrm{HTG}} & = & \text { cost of natural gas for heating }(\$ / \text { therm) } \\ 1000 / 3.41 & = & \text { conversion factor }(\mathrm{kWh} / \mathrm{MMBtu}) \\ 10 & = & \text { conversion factor (therm/MMBtu) }\end{array}$

\section{Step $7 \quad$ Choose your next steps}

Use these initial estimates to decide whether to perform further site-specific analyses, engage vendors or contractors to price retrofit or new construction options, or test door operation changes. Appendix $C$ provides suggestions about how to implement this measure. 


\section{References}

ASHRAE. (2002). ASHRAE Guideline 14-2002, Measurement of Energy and Demand Savings. Atlanta, GA: American Society of Heating, Refrigerating and Air-Conditioning Engineers, Inc.

ASHRAE. (2007). ANSI/ASHRAE/IESNA Standard 90.1-2007, Energy Standard for Buildings Except Low-Rise Residential Buildings. Atlanta, GA: American Society of Heating, Refrigerating and Air-Conditioning Engineers, Inc.

ASHRAE. (2009). ASHRAE Handbook: Fundamentals. Atlanta, GA: American Society of Heating, Refrigerating and AirConditioning Engineers, Inc.

DOE (2004). Adapted from a climate zone map developed for the U.S. DOE and first published in ASHRAE Standard 90.1-2004. Available at http://apps1.eere.energy.gov/buildings/publications/pdfs/building_america/ba_climateguide_7_1.pdf. Last accessed December 2010.

DOE (2010). Commercial Reference Buildings. www1.eere.energy.gov/buildings/commercial_initiative/reference_buildings.html.

DOE (2011a). EnergyPlus Energy Simulation Software, Version 6.0. Washington, D.C.: U.S. Department of Energy. http://apps1. eere.energy.gov/buildings/energyplus/.

DOE (2011b). EnergyPlus Energy Simulation Software: Weather Data Sources. http://apps1.eere.energy.gov/buildings/energyplus/weatherdata_sources.cfm.

Haberl, J.S., Culp C.; Claridge, D.E. (2005). ASHRAE's Guideline 14-2002 for Measurement of Energy and Demand Savings: How to Determine What Was Really Saved by the Retrofit, pp. 1-13.

Memtech. (2011). Weatherstripping Door Seals. Retrieved Aug. 23, 2011, from www.memtechbrush.com/weatherstrip/ door-weatherstripping.htm.

NBE Australia. (2009). PVC Strip Door Installation. Installation manual retrieved Aug. 15, 2011, from www.nbeaustralia.com.au/ Data\%20Downloads/install_pvc_strip_door_ss.pdf.

PNNL. (2009). Vestibule Case Study. Retrieved Aug. 15, 2011, from the Building Energy Codes Resource Center at http://resourcecenter.pnl.gov/cocoon/morf/ResourceCenter/article/1484.

Wulfinghoff, D.R. (1999). Energy Efficiency Manual. Wheaton, MD: Energy Institute Press, pp. 826-857.

Yuill, G.K. (1996). Impact of High Use Automatic Doors on Infiltration. Project 763-TRP, American Society of Heating, Refrigerating and Air-Conditioning Engineers, Inc., Atlanta, GA. 


\section{Appendix A}

\section{Vestibule Additions: Background and Development of Equations}

Overview

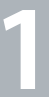

Option A:

Simplified

Method

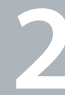

Option B

Simulation

Method

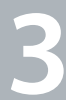

Option C

Leverage

Example
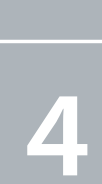

Option A:

Simplified

Method

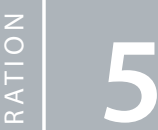

Option B:

Simulation

Method

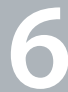

Option C:

Leverage

Example

References

Appendices

This appendix explains how the instructions in Section 1, Section 2, and Section 3 were derived. The methodologies reference a previous study of vestibule infiltration (Yuill 1996), Chapter 16 of the ASHRAE Handbook of Fundamentals (ASHRAE 2009), and an analysis conducted by NREL.

\section{Derivation of Airflow Coefficients for Infiltration}

In the instructions in Section 1 and Section 2, airflow coefficients must be derived before infiltration rates and related energy savings are estimated. In Section 3, your building is assumed to have similar infiltration rates, so you do not need to separately estimate additional infiltration rates.

The Yuill study provides two sets of airflow coefficients: one does not correct for the presence of a person in the doorway; the other does. This document uses the latter set of coefficients.

The Yuill study also provides coefficients for multiple door types and configurations. To represent a typical baseline case and a high-efficiency alternative, this simulation example in Section 3 uses the average value of the "no vestibule" options and the most efficient of the "with vestibule" options. There was very little variation in performance within the "no vestibule" and "with vestibule" categories. Therefore, selection of alternative options within the scope of the Yuill study is expected to have minimal impact on savings estimates. Many other design options are possible; however, analysis of additional designs was outside the scope of the simulation example.

A second-order polynomial best-fit line was used to summarize selected airflow coefficients from the Yuill study. This is provided as Equations 1-1 through 1-4 and Equations 2-1 through 2-4.

\section{Derivation of Pressure Coefficients}

The methodology from the section titled "Air Leakage Through Automatic Doors" in Chapter 16 of ASHRAE (2009) was used to derive the pressure coefficients in Section 1 and Section 2. The methodology involves calculating a local wall pressure coefficient, $C_{S}$, for low-rise buildings. This is then used to find the local wind pressure coefficient, $C_{p}$. These values vary with wind angle, so Table 1-1 and Table 2-1 provide two options: $C_{p}$ equals 0.70 when the absolute value of $C_{S}$ is at its maximum value of about $0.5 ; C_{p}$ equals 0.45 when the absolute value of $C_{S}$ is about 0.25 . The values also assume that for low-rise retail buildings, stack effect would be negligible relative to wind pressure.

For a more precise estimate, consult ASHRAE (2009).

\section{Derivation of Factors and Multipliers}

Depending on whether you choose the methodology of Section 1, Section 2, or Section 3, intermediate factors and multipliers may be needed to complete energy savings estimates. The derivation of these factors and multipliers is explained below.

Equation A-1, adapted from ASHRAE (2009), was the basis of additional equations in this document.

$$
\mathrm{Q}=1.08 \times \mathrm{CFM} \times \Delta \mathrm{T}
$$

where:

$\begin{array}{lll}\mathrm{Q} & = & \text { infiltration load }(\mathrm{Btu} / \mathrm{h}) \\ \mathrm{CFM} & = & \text { infiltration rate }(\mathrm{cfm}) \\ \Delta \mathrm{T} & = & \text { indoor-to-outdoor temperature difference }\left({ }^{\circ} \mathrm{F}\right) \\ 1.08 & = & \text { conversion factor }\left(\mathrm{Btu} / \mathrm{h} / \mathrm{cfm} /{ }^{\circ} \mathrm{F}\right)\end{array}$

The conversion factor of 1.08 assumes the density of air is $0.075\left(\mathrm{lb} / \mathrm{ft}^{3}\right)$ and the specific heat of air is $0.24\left(\mathrm{Btu} / \mathrm{lb} /{ }^{\circ} \mathrm{F}\right)$. 
Equation A-1 can be rearranged to calculate an infiltration load, $\mathrm{L}_{\mathrm{FN}}$, which is normalized by the flow rate of infiltration as shown in Equation A-2:

$$
L_{F N}=1.08 \times \Delta T
$$

where:

$\begin{array}{lll}\mathrm{L}_{\mathrm{FN}} & = & \text { flow-normalized infiltration load }(\mathrm{Btu} / \mathrm{h} / \mathrm{cfm}) \\ \Delta \mathrm{T} & = & \text { monthly average indoor-to-outdoor temperature difference }\left({ }^{\circ} \mathrm{F}\right) \\ 1.08 & = & \text { conversion factor }\left(\mathrm{Btu} / \mathrm{h} / \mathrm{cfm} /{ }^{\circ} \mathrm{F}\right)\end{array}$

Indoor-to-outdoor temperature differences, $\Delta \mathrm{T}$, were calculated by referencing data from Typical Meteorological Year Version 2 (TMY2) weather data files (DOE 2011b). These files provide monthly average temperatures for each hour of the day.

The flow-normalized infiltration load for a given time period can then be translated into a flow-normalized HVAC power requirement, $\mathrm{P}_{\mathrm{FN}}$, using assumptions for HVAC system efficiency in Equation $\mathrm{A}-3$ :

$$
\mathrm{P}_{\mathrm{FN}}=\mathrm{L}_{\mathrm{FN}} /(\mathrm{COP} \text { or } \eta)
$$

where:

$\begin{array}{lll}\mathrm{P}_{\mathrm{FN}} & = & \text { flow-normalized HVAC power requirement }(\mathrm{Btu} / \mathrm{h} / \mathrm{cfm}) \\ \mathrm{LFN}_{\mathrm{FN}} & = & \text { flow-normalized infiltration load }(\mathrm{Btu} / \mathrm{h} / \mathrm{cfm}) \\ \mathrm{COP} & = & \text { coefficient of performance (dimensionless) } \\ \eta & = & \text { heating efficiency (dimensionless) }\end{array}$

A flow-normalized climate factor, $\mathrm{F}_{\mathrm{CF}}$, can then be calculated using the flow-normalized HVAC power requirement.

$$
F_{C F}=P_{F N} \times D \times 10^{-6}
$$

where:

$$
\begin{array}{lll}
\mathrm{F}_{\mathrm{CF}} & = & \text { flow-normalized climate factor }(\mathrm{MMBtu} \cdot \text { day } / \mathrm{h} / \mathrm{cfm}) \\
\mathrm{P}_{\mathrm{FN}} & = & \text { flow-normalized HVAC power requirement }(\mathrm{Btu} / \mathrm{h} / \mathrm{cfm}) \\
\mathrm{D} & = & \text { number of days in analysis period (days) }
\end{array}
$$

To account for seasonal variations in outdoor temperature, monthly average flow-normalized climate factors were calculated for each month of a typical year. The monthly values were then summed to produce an annual average.

For the methodology of Section 1, Table 1-2 provides the annual average flow-normalized climate factors for each of the analyzed climate zones. If you know your door typically opens and closes within specific timeframes, you can use the time-ofday multipliers in Table 1-3 to adjust your estimate. TMY weather data were used to derive these multipliers, excluding data from hours outside the applicable time-of-day ranges.

The cooling and heating fraction multipliers in Table 1-4 and Table 3-2 reflect the proportion of energy savings potential that is attributable to cooling energy savings or heating energy savings. These are annual values, so they take into account seasonal changes. The breakdown depends on the proportion of time infiltration contributes to the cooling or heating load and depends on HVAC system efficiencies. In this analysis, the following efficiencies were assumed based on requirements in ASHRAE Standard 90.1-2007:

- Cooling system COP of 3.7

- Natural gas heating system efficiency of $80 \%$.

To represent typical, generic retail building conditions, the balance point temperature was assumed to be $55^{\circ} \mathrm{F}$, and the average indoor temperature was assumed to be $71^{\circ} \mathrm{F}$. Outdoor temperature assumptions were based on TMY data.

The cooling and heating fraction multipliers were then calculated as follows:

- When the outdoor temperature exceeded the balance point, the HVAC system was assumed to be cooling.

- If the average outdoor temperature also exceeded the indoor temperature, door infiltration was assumed to increase the cooling load.

- If the average outdoor temperature was lower than the indoor temperature, door infiltration was assumed to reduce the cooling load.

- When the outdoor temperature was lower than the balance point, the HVAC system was assumed to be heating. Infiltration was then assumed to increase the heating load. 


\section{Equations for Energy Savings and Energy Cost Savings}

In Section 1, the preceding factors, multipliers, and other user inputs can then be related to energy savings potential by using Equation A-5. To derive Equation A-5, whole-building simulation was used to compare multiple cases in which climate zone and infiltration rates were varied. Within each climate zone, energy savings potential had a fairly linear relationship with respect to changes in the product of infiltration rate and open hours per day. Based on this observation, Equation A-5 was derived to estimate energy savings in accordance with user inputs for door and vestibule use.

$$
E_{\text {savings }}=F_{C F} \times M_{T} \times H \times\left(C F M_{C}-C F M_{P}\right)
$$

where:

$$
\begin{array}{lll}
\mathrm{E}_{\mathrm{savings}} & = & \text { annual whole-building energy savings potential (MMBtu) } \\
\mathrm{F}_{\mathrm{CF}} & = & \text { flow-normalized climate factor (MMBtu-day } / \mathrm{h} / \mathrm{cfm}) \\
\mathrm{M}_{\mathrm{T}} & = & \text { time-of-day multiplier (dimensionless) } \\
\mathrm{H} & = & \text { entrance operating hours per day, annual average }(\mathrm{h} / \mathrm{day}) \\
\mathrm{CFM} & = & \text { average infiltration rate during hours of use for current strategy }(\mathrm{cfm}) \\
\mathrm{CFM} & = & \text { average infiltration rate during hours of use for proposed strategy }(\mathrm{cfm})
\end{array}
$$

Option B:

Simulation

Method

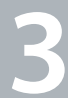

Option C:

Leverage

Example

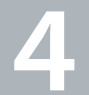

Option A:

Simplified

Method

Option B:

Simulation

Method

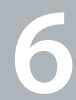

Option C

Leverage

Example

References

Then, energy savings can be translated into energy cost savings with Equation A-6:

$$
\mathrm{C}_{\text {savings }}=\mathrm{E}_{\text {savings }} \times\left(1000 / 3.41 \times \mathrm{M}_{\mathrm{CLG}} \times \mathrm{C}_{\mathrm{CLG}}+10 \times \mathrm{M}_{\mathrm{HTG}} \times \mathrm{C}_{\mathrm{HTG}}\right)
$$

where:

$$
\begin{array}{lll}
\mathrm{C}_{\text {savings }} & = & \text { annual energy cost savings potential }(\$) \\
\mathrm{E}_{\text {savings }} & = & \text { annual energy savings potential }(\mathrm{MMBtu}) \\
\mathrm{M}_{\mathrm{CLG}} & = & \text { cooling fraction multiplier (dimensionless) } \\
\mathrm{C}_{\mathrm{CLG}} & = & \text { cost of cooling }(\$ / \mathrm{kWh}) \\
\mathrm{M}_{\mathrm{HTG}} & = & \text { heating fraction multiplier (dimensionless) } \\
\mathrm{C}_{\mathrm{HTG}} & = & \text { cost of heating }(\$ / \text { therm) } \\
1000 / 3.41 & = & \text { conversion factor }(\mathrm{kWh} / \mathrm{MMBtu}) \\
10 & = & \text { conversion factor (therm/MMBtu) }
\end{array}
$$

In Section 2, you determine energy savings and energy cost savings potential through your own simulation.

In Section 3, you determine energy savings potential with the assistance of a lookup table, Table 3-1. Then you can translate energy savings into energy cost savings with Equation A-6. 


\section{Appendix B}

Door Operation Changes: Background and Development of Equations

This appendix explains how the instructions in Section 4, Section 5, and Section 6 were derived. The methodologies reference Chapter 16 of the ASHRAE Handbook of Fundamentals (ASHRAE 2009) and an analysis conducted by NREL.

\section{Infiltration Assumptions}

The energy measures examined in this section involve a door that is open for an extended period, which had two major impacts on how methodologies for estimating infiltration were designed:

- This condition can be modeled with the capabilities of the whole-building energy simulation program, EnergyPlus (DOE 2011a).

- Between door operation changes and vestibule additions, the former are assumed to be more sensitive to wind and stack effects. (Vestibule analyses are assumed to be more sensitive to the average rate of door traffic, which is related to how frequently the vestibule doors open and close.)

To develop the instructions in Section 4, Section 5, and Section 6, a large retail building model was created by modifying prior whole-building energy models developed by NREL (see the Acknowledgments section). The "Zone Ventilation: Wind and Stack Open Area" object in EnergyPlus was used to calculate infiltration rates. This object accounted for wind and stack effects across the door opening. For more information about how EnergyPlus models infiltration, see the EnergyPlus "Engineering Reference" documentation that accompanies the EnergyPlus download (DOE 2011a).

Infiltration rates vary by climate because of climate-specific outdoor conditions, such as wind speed, wind direction, and temperature. Therefore, whole-building energy simulations were conducted for multiple locations, and in each case, infiltration rates were estimated every five minutes for a TMY.

Results from the NREL simulations are used as follows:

- Section 4 enables you to adjust the infiltration rates from the example simulations based on user inputs for effective door area.

- Section 5 provides monthly average infiltration rates from the example simulations, which you can use or adapt for your own simulations.

- Section 6 provides instructions about how to leverage energy savings results if your building is similar to the modeled example.

To develop climate factors and other multipliers for these sections, the five-minute-interval infiltration rates were averaged over each month for an example case and then adapted as described below.

\section{Derivation of Factors and Multipliers}

Depending on whether you choose the methodology of Section 4, Section 5, or Section 6, you may need intermediate factors and multipliers to complete energy savings estimates. The derivation of these factors and multipliers is explained below.

Equation B-1, adapted from ASHRAE (2009), was the basis of additional equations in this document.

$$
\mathrm{Q}=1.08 \times \mathrm{CFM} \times \Delta \mathrm{T}
$$

where:

$$
\begin{array}{lll}
\mathrm{Q} & = & \text { infiltration load }(\mathrm{Btu} / \mathrm{h}) \\
\mathrm{CFM} & = & \text { infiltration rate }(\mathrm{cfm}) \\
\Delta \mathrm{T} & = & \text { indoor-to-outdoor temperature difference }\left({ }^{\circ} \mathrm{F}\right) \\
1.08 & = & \text { conversion factor }\left(\mathrm{Btu} / \mathrm{h} / \mathrm{cfm} /{ }^{\circ} \mathrm{F}\right)
\end{array}
$$

The conversion factor of 1.08 assumes the density of air is $0.075\left(\mathrm{lb} / \mathrm{ft}^{3}\right)$ and the specific heat of air is $0.24\left(\mathrm{Btu} / \mathrm{lb} /{ }^{\circ} \mathrm{F}\right)$. 
Overview

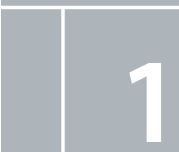

Option A:

Simplified

Method

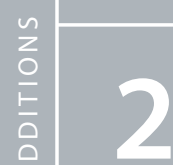

Option B:

Simulation

Method

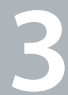

Option C:

Leverage

Example

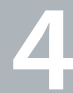

Option A:

Simplified

Method
To determine area-normalized climate factors, an example case with a $230-\mathrm{ft}^{2}$ effective door area was assessed with wholebuilding simulation. Findings from the example case were used to produce generalized equations and instructions for estimating savings potential. These instructions can be used with various baseline and alternative effective door areas.

Equation B-1 can be rearranged to calculate an infiltration load, $\mathrm{L}_{\mathrm{AN}}$, which is normalized by the effective door area as shown in Equation B-2.

$$
\mathrm{L}_{\mathrm{AN}}=1.08 \times \Delta \mathrm{T} \times\left(\mathrm{CFM}_{230} / 230\right)
$$

where:

$\begin{array}{lll}\mathrm{L}_{\mathrm{AN}} & = & \text { area-normalized infiltration load }\left(\mathrm{Btu} / \mathrm{h} / \mathrm{ft}^{2}\right) \\ \Delta \mathrm{T} & = & \text { monthly average indoor-to-outdoor temperature difference }\left({ }^{\circ} \mathrm{F}\right) \\ 1.08 & = & \text { conversion factor }\left(\mathrm{Btu} / \mathrm{h} / \mathrm{cfm} /{ }^{\circ} \mathrm{F}\right) \\ \mathrm{CFM}_{230} & = & \text { infiltration rate for an effective door area of } 230 \mathrm{ft}^{2}(\mathrm{cfm}) \\ 230 & = & \text { effective door area }\left(\mathrm{ft}^{2}\right)\end{array}$

Indoor-to-outdoor temperature differences, $\Delta T$, were calculated by referencing data from TMY2 weather data files (DOE 2011b). These files provide monthly average temperatures for each hour of the day.

The area-normalized infiltration load for a given time period can then be translated into an area-normalized HVAC power requirement, $\mathrm{P}_{\mathrm{AN}}$, using assumptions for HVAC system efficiency in Equation $\mathrm{B}-3$ :

$$
P_{\text {AN }}=L_{A N} /(C O P \text { or } \eta)
$$

where:

$$
\begin{array}{lll}
\mathrm{P}_{\mathrm{AN}} & = & \text { area-normalized HVAC power requirement }\left(\mathrm{Btu} / \mathrm{h} / \mathrm{ft}^{2}\right) \\
\mathrm{L}_{\mathrm{AN}} & = & \text { area-normalized infiltration load }\left(\mathrm{Btu} / \mathrm{h} / \mathrm{ft}^{2}\right) \\
\mathrm{COP} & = & \text { coefficient of performance (dimensionless) } \\
\eta & = & \text { heating efficiency (dimensionless) }
\end{array}
$$

An area-normalized climate factor, $\mathrm{F}_{\mathrm{CA}}$, can then be calculated using the area-normalized HVAC power requirement.

$$
F_{C A}=P_{A N} \times D \times 10^{-6}
$$

where:

$$
\begin{array}{lll}
\mathrm{F}_{\mathrm{CA}} & = & \text { area-normalized climate factor }\left(\mathrm{MMBtu} \cdot \text { day } / \mathrm{h} / \mathrm{ft}^{2}\right) \\
\mathrm{P}_{\mathrm{AN}} & = & \text { area-normalized HVAC power requirement }\left(\mathrm{Btu} / \mathrm{h} / \mathrm{ft}^{2}\right) \\
\mathrm{D} & = & \text { number of days in analysis period (days) }
\end{array}
$$

To account for seasonal variations in outdoor temperature, area-normalized climate factors were calculated for each month, and the monthly values were then summed to produce an annual average.

For the methodology in Section 4, Table 4-1 provides the annual average flow-normalized climate factors for each of the analyzed climate zones. If you know your door typically opens and closes within specific timeframes, you can use the time-ofday multipliers in Table 4-2 to adjust your estimate. Otherwise, assume a time-of-day multiplier of 1. TMY weather data were used to derive these multipliers, excluding data from hours outside the applicable time-of-day ranges.

The cooling and heating fraction multipliers in Table 4-3 and Table 6-3 reflect the proportion of energy savings potential that is attributable to cooling energy savings or heating energy savings. These are annual values, so they take into account seasonal changes. The breakdown depends on HVAC system efficiencies and the proportion of time infiltration contributes to the cooling or heating load. In this analysis, the following efficiencies were assumed based on requirements in ASHRAE Standard 90.1-2007:

- Cooling system COP of 3.7

- Natural gas heating system efficiency of $80 \%$.

To represent typical, generic retail building conditions, the balance point temperature was assumed to be $55^{\circ} \mathrm{F}$, and the average indoor temperature was assumed to be $71^{\circ} \mathrm{F}$. Outdoor temperature assumptions were based on TMY data. The cooling and heating fraction multipliers were then calculated as follows: 
- When the outdoor temperature exceeded the balance point, the HVAC system was assumed to be cooling.

- If the average outdoor temperature also exceeded the indoor temperature, door infiltration was assumed to increase the cooling load.

- If the average outdoor temperature was lower than the indoor temperature, door infiltration was assumed to reduce the cooling load.

- When the outdoor temperature was lower than the balance point, the HVAC system was assumed to be heating. Infiltration was then assumed to increase the heating load.

\section{Equations for Energy Savings and Energy Cost Savings}

In Section 4, the preceding factors, multipliers, and other user inputs can then be related to energy savings potential by using Equation B-5. To derive Equation B-5, whole-building simulation was used to compare multiple cases in which climate zone was varied; effective door area varied from 0 to $230 \mathrm{ft}^{2}$; and the time the door was left open varied from 0 to 3 hours per day. Within each climate zone, energy savings potential had a fairly linear relationship with respect to changes in the product of effective door area and open hours per day. Based on this observation, Equation B-5 was derived to estimate energy savings in accordance with user inputs for door use.

$$
E_{\text {savings }}=F_{C A} \times M_{T} \times\left(A_{C} \times H_{C}-A_{P} \times H_{P}\right)
$$

where:

$\begin{array}{lll}\mathrm{E}_{\text {savings }} & = & \text { annual energy savings potential (MMBtu) } \\ \mathrm{F}_{\mathrm{CA}} & = & \text { area-normalized climate factor }\left(\mathrm{MMBtu} \cdot \text { day } / \mathrm{h} / \mathrm{ft}^{2}\right) \\ \mathrm{M}_{\mathrm{T}} & = & \text { time-of-day multiplier (dimensionless) } \\ \mathrm{A}_{\mathrm{C}} & = & \text { effective door area for current strategy }\left(\mathrm{ft}^{2}\right) \\ \mathrm{H}_{\mathrm{C}} & = & \text { hours per day door is left open for current strategy }(\mathrm{h} / \mathrm{day}) \\ \mathrm{A}_{\mathrm{P}} & = & \text { effective door area for proposed strategy }\left(\mathrm{ft}^{2}\right) \\ \mathrm{H}_{\mathrm{P}} & = & \text { hours per day door is left open for proposed strategy }(\mathrm{h} / \text { day) }\end{array}$

Then, energy savings can be translated into energy cost savings with Equation B-6:

$$
\mathrm{C}_{\text {savings }}=\mathrm{E}_{\text {saving }} \times\left(1000 / 3.41 \times \mathrm{M}_{\mathrm{CLG}} \times \mathrm{C}_{\mathrm{CLG}}+10 \times \mathrm{M}_{\mathrm{HTG}} \times \mathrm{C}_{\mathrm{HTG}}\right)
$$

where:

$\begin{array}{lll}\mathrm{C}_{\text {savings }} & = & \text { annual energy cost savings potential }(\$) \\ \mathrm{E}_{\text {savings }} & = & \text { annual energy savings potential (MMBtu) } \\ \mathrm{M}_{\mathrm{CLG}} & = & \text { cooling fraction multiplier (dimensionless) } \\ \mathrm{C}_{\mathrm{CLG}} & = & \text { cost of cooling }(\$ / \mathrm{kWh}) \\ \mathrm{M}_{\mathrm{HTG}} & = & \text { heating fraction multiplier (dimensionless) } \\ \mathrm{C}_{\mathrm{HTG}} & = & \text { cost of heating }(\$ / \text { therm) } \\ 1000 / 3.41 & = & \text { conversion factor }(\mathrm{kWh} / \mathrm{MMBtu}) \\ 10 & = & \text { conversion factor (therm/MMBtu) }\end{array}$


Overview

1

Option A:

Simplified

Method

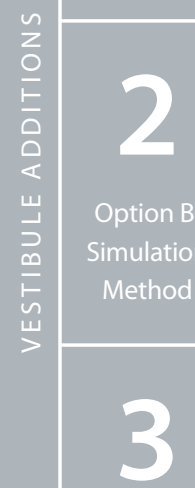

Option C:

Leverage

Example

4

Option A:

Simplified

Method

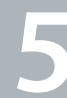

Option B:

Simulation

Method

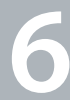

Option C

Leverage

Example

References
In Section 5, you determine energy savings and energy cost savings potential through your own simulation.

In Section 6, you select an energy savings factor from Table 6-2; this factor reflects climate-specific variations in energy savings potential from simulations of an example large retail building. You enter this factor into Equation B-7:

$$
E_{\text {savings }}=F_{E S} \times\left(A_{C} \times H_{C}-A_{P} \times H_{P}\right)
$$

where:

$$
\begin{array}{lll}
\mathrm{E}_{\text {savings }} & = & \text { annual whole-building energy savings potential (MMBtu) } \\
\mathrm{FES}_{\mathrm{ES}} & = & \text { energy savings factor }\left(\mathrm{MMBtu} \cdot \text { day } / \mathrm{h} / \mathrm{ft}^{2}\right) \\
\mathrm{A}_{\mathrm{C}} & = & \text { effective door area for current strategy }\left(\mathrm{ft}^{2}\right) \\
\mathrm{H}_{\mathrm{C}} & = & \text { hours per day door is left open for current strategy }(\mathrm{h} / \mathrm{day}) \\
\mathrm{A}_{\mathrm{P}} & = & \text { effective door area for proposed strategy }\left(\mathrm{ft}^{2}\right) \\
\mathrm{H}_{\mathrm{P}} & = & \text { hours per day door is left open for proposed strategy }(\mathrm{h} / \text { day })
\end{array}
$$

Then you can translate energy savings into energy cost savings with Equation B-6. 


\section{Appendix C}

\section{Additional Considerations and Tips for Choosing Entrance Strategies}

Strategies to help reduce infiltration through doors include:

- Vestibule additions

- Door operation changes

- Quick-opening door strategies

- Partial opening strategies.

- Other considerations

- Weatherstripping applications

- Regular inspections

- Monitoring and verification.

Proper installation and regular maintenance are critical to successfully reduce infiltration and associated energy use. Practical tips and considerations for implementing such measures are discussed in the following section.

\section{Vestibule Additions}

Proper design is critical for vestibules to effectively reduce infiltration and maximize savings. Considerations include:

- Minimize the time the exterior and interior vestibule doors are open simultaneously; this is affected by the distance between doors, the traffic rate, and, in the case of sensor-controlled doors, the delay setting. You will need to weigh the tradeoff between energy savings and construction cost. For example, you could increase the distance between interior and exterior doors by specifying a long vestibule with an L-shaped path between doors, but this would cost more than a smaller vestibule.

- Consider site-specific wind patterns.

- If the prevailing wind blows toward the building entrance, consider a vestibule design where the exterior doors are on the left or right side of the vestibule, rather than directly across from the interior doors. This creates an obstruction that can reduce the infiltration rate.

- Chapter 24 of the ASHRAE Handbook of Fundamentals (ASHRAE 2009) provides more information about how windinduced pressure can vary with wind angle.

The "Vestibule Case Study" by the Pacific Northwest National Laboratory Building Energy Codes Resource Center (see PNNL 2009) provides an explanation of relevant standards and how to interpret them. This case study refers to standards that may differ from those referenced by codes in your jurisdiction. For example, it references ASHRAE Standard 90.1-2004, stating where vestibules are required. If your jurisdiction uses a different edition of Standard 90.1, the requirements may differ. Consult the codes in your jurisdiction to determine which standards apply.

\section{Door Operation Changes}

Some retail buildings have customer doors used for large item pickups or shipping and receiving doors used by retailers and their product distributors. Methods for reducing energy use at such doors include:

- Instruct delivery personnel to close doors more frequently. This may also affect delivery time, however, so you may first wish to estimate energy and delivery cost impacts.

- Install sensor-operated quick-opening doors. This may reduce the time doors are open and mitigate delivery cost impacts.

- Employ partial door opening strategies. You may want to use a lower default overhead door height for most deliveries and switch to the maximum door height for larger deliveries. Another strategy is to install curtains to reduce effective door area. 


\section{Quick-Opening Doors}

Some doors are marketed by manufacturers as "quick-opening doors"; these tend to be lighter weight and have faster operating speeds than other doors. Quick-opening doors are available with operating speeds that range from slightly faster to more than 10 times faster than a typical door. These may present an energy-saving alternative if the baseline case includes a door that is left open for extended periods. To save energy, the quick-opening door would have to be convenient to open and close frequently, which may be facilitated with sensors for automatic operation.

Options include:

- Quick-Opening Supplemental Door: These doors can be installed on the interior of a building entrance (Wulfinghoff 1999). During periods of high traffic, the heavier, more insulated door would remain open, while the quick-opening door would open and close with door traffic. At other times, the heavier door could be closed to maximize insulation and provide security.

Quick-Opening Stand-Alone Door: These doors may be heavier than supplemental doors to provide security and still offer a higher operating speed.

Switching to a quick-opening door may change the amount of energy consumed by the door motor. When considering these measures, ask door manufacturers if they have information about motor power and typical energy use. This information can help you estimate whether the energy savings associated with infiltration reduction will outweigh any added motor energy use from increased door operation.

\section{Partial Opening Strategies for Delivery and Bay Doors}

Strip curtain doors: These can be installed to reduce infiltration effects. These doors are not intended to withstand strong winds or large pressure differentials.

Manufacturers can provide installation tips that can improve the performance of strip curtain doors. For example, one manufacturer suggests:

- Allowing the strips to drag on the floor and increasing the strip overlap to improve effectiveness

- Mounting the head rail of the strips at least $3 \frac{1}{4}$ feet above the door opening if the entering vehicle or equipment exceeds $70 \%$ of the height or width of the door opening to reduce wear and extend life (NBE Australia 2009).

Door opening height considerations: Another possible solution would be to allow for, either manually or automatically, various door opening heights where feasible. Large bay doors could open to a low default overhead door height for most deliveries, switching to full height only when necessary.

\section{Other Considerations}

\section{Weatherstripping Applications}

Weatherstripping can be added around all edges of doors and should fit snugly between doors and frames, compressing slightly to create a tight air seal.

Manufacturers can provide tips on weatherstripping applications. For example, one manufacturer suggests:

- For hinged doors: Apply thresholds at the bases of doors and foam stripping on corners, jambs, and astragals.

- For large industrial or commercial rolling or sliding doors: Apply heavy-duty brushes at the heads, jambs, and bases of the doors; apply rope seals near the hinge of a dock leveler to form a seal when the leveler is locked in place (Memtech 2011).

Further suggestions for applying weatherstripping include:

- Apply compressible weatherstripping on the outward facing side of the door frame to ensure sealing around locking mechanisms at the tops of doors.

- Apply rubber gaskets or stiff nylon brushes to extend the life of the weatherstripping. The effectiveness of soft synthetic stripping may degrade over a short time if doors are frequently used.

\section{Regular Inspections}

With time and use, doors lose their original alignment and leave gaps around their perimeters. If exterior doors are misaligned, they should be adjusted to ensure they seal on all sides when closed. Building managers should inspect door alignment and weatherstripping regularly; consult manufacturers for a suggested inspection and maintenance schedule. Take time to examine each entrance. If there are visible cracks around the doors, the doors may be misaligned or the weatherstripping may need to be replaced. 
One simple test is to hold a smoke pen a few inches away from door edges and note the turbulence of the smoke. Significant turbulence indicates that the door needs adjustment or the weatherstripping needs to be replaced. Another test is to perform a thermal imaging scan of the door entrance to look for significant temperature differences, paying close attention to the door frame.

At loading docks with compression seals, ensure delivery trucks are situated to create a tight seal, and periodically inspect the seal material for wear.

\section{Monitoring and Verification Resources}

For suggestions about how to track energy savings associated with implementing vestibule additions or door operation changes, see the following resources:

- ASHRAE Guideline 14-2002 available at http://webstore.ansi.org/RecordDetail.aspx?sku=ASHRAE+Guideline+14-2002.

For an overview on ASHRAE Guideline 14-2002, details on how it was developed, and an explanation of how it should be used in combination with other protocols, see "ASHRAE's Guideline 14-2002 for Measurement of Energy and Demand Savings: How to Determine What was Really Saved by the Retrofit" by Haberl et al. (2005), available at www-esl.tamu.edu/ docs/terp/2005/ESL-IC-05-10-50.pdf.

- International Protocol for Measurement and Verification available at www.evo-world.org/index.php?option=com_content \&task=view\&id=272\&ltemid $=279$. 


\section{Appendix D}

DOE Climate Zones and Representative Cities
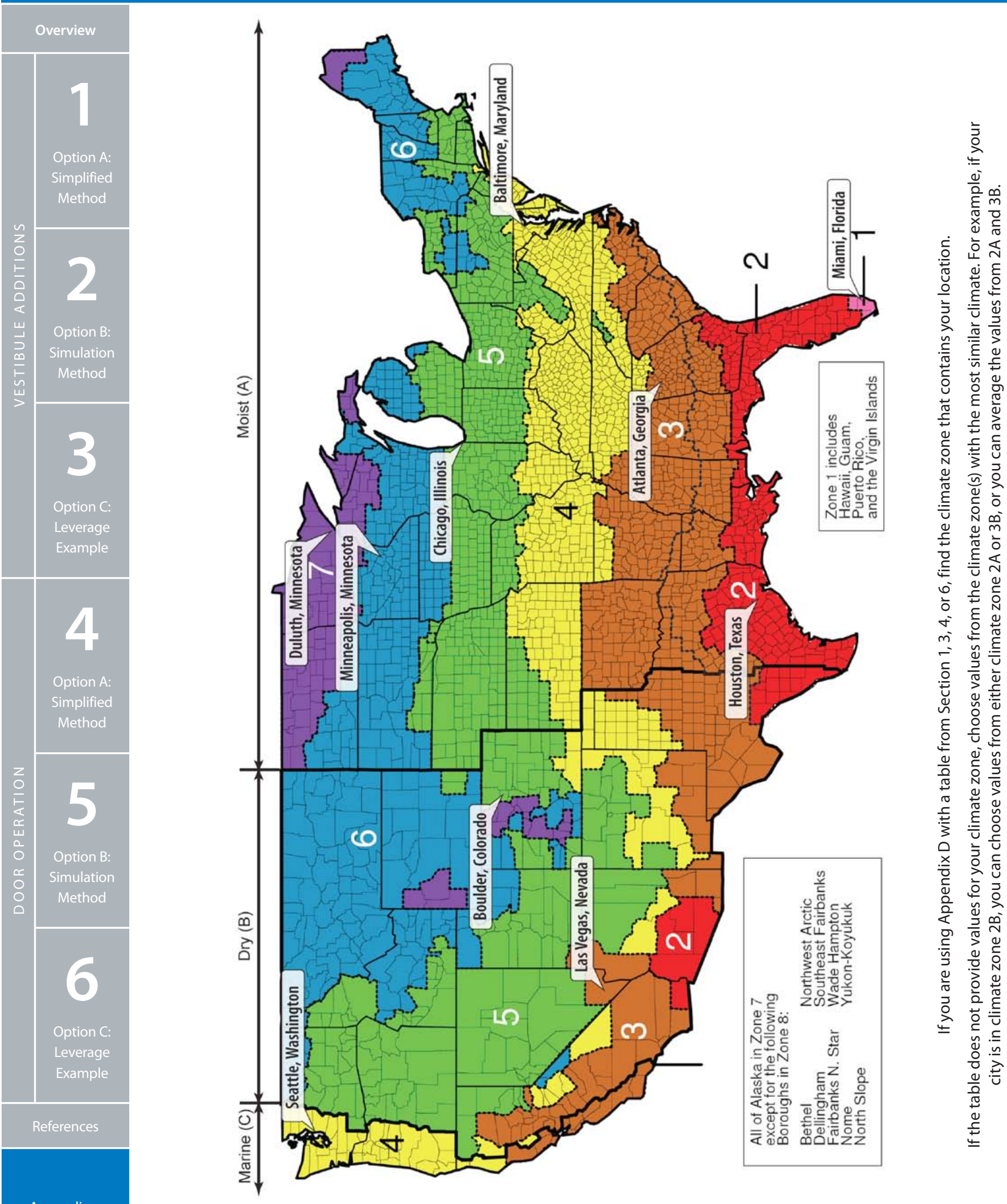


\section{Appendix E - Worksheet for Section 1}

Vestibule Additions: Simplified Method

This worksheet can be used in combination with Section 1 of the guide.

\section{Step 1 Estimate airflow coefficients based on door uses per hour}

The following equation can be used to determine the airflow coefficients based on door uses per hour for cases with and without a vestibule:

$$
\mathrm{C}_{1} \times \mathrm{PPH}^{2}+\mathrm{C}_{2} \times \mathrm{PPH}-\mathrm{C}_{3}=\mathrm{C}_{\mathrm{A}}
$$

Table E-1. Coefficients for the vestibule cases

\begin{tabular}{|l|c|c|c|}
\hline \multicolumn{1}{|c|}{ Vestibule Option } & $C_{1}$ & $C_{2}$ & $C_{3}$ \\
\hline $\begin{array}{l}\text { Vestibule with swinging doors } \\
\text { Vestibule with sliding doors, where the inner } \\
\text { and outer doors are across from each other }\end{array}$ & -0.0016 & 2.722 & 8.591 \\
\hline $\begin{array}{l}\text { Vestibule with sliding doors, where the } \\
\text { outer doors are on the left or right side of } \\
\text { the vestibule }\end{array}$ & -0.0013 & 2.479 \\
\hline
\end{tabular}

Calculate the airflow coefficient, $C_{A}$, with, for the case with a vestibule:

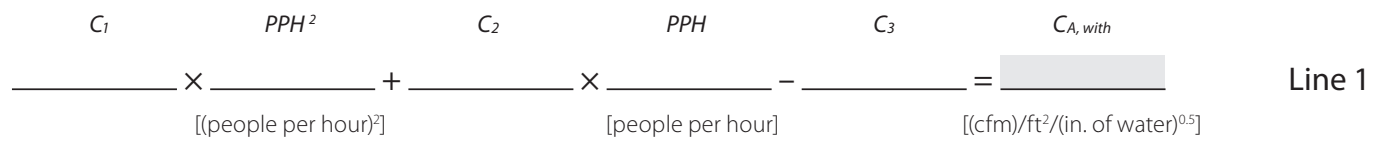

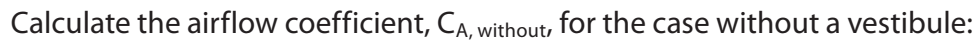

$$
\begin{aligned}
& \mathrm{PPH}^{2} \quad P P H \\
& -0.0024 \times \underset{\left[(\text { people per hour })^{2}\right]}{\times}+ \\
& 3.813 \\
& \times \overline{\text { [people per hour] }}
\end{aligned}
$$

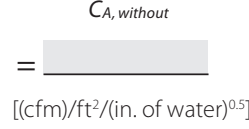

\section{Step 2 Identify a pressure factor}

Choose the appropriate pressure factor, $R_{p}$, from Table 1-1.

\section{Step 3 Estimate your infiltration rates}

The following equation can be used to determine your infiltration rates for cases with and without a vestibule:

$$
\mathrm{C}_{\mathrm{A}} \times \mathrm{A} \times \mathrm{R}_{\mathrm{p}}=\mathrm{CFM}
$$

Calculate the infiltration rate, $\mathrm{CFM}_{\mathrm{P}}$, for the case with a vestibule (i.e., infiltration rate for the proposed case):

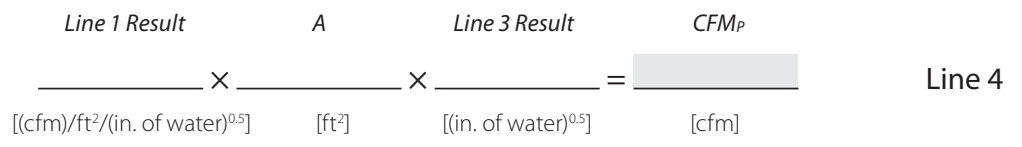


Calculate the infiltration rate, $\mathrm{CFM}_{\mathrm{C}}$, for the case without a vestibule (i.e., infiltration rate for the current case):

$\underset{\left[(\mathrm{cfm}) / \mathrm{ft}^{2} /\left(\mathrm{in}_{\text {of }} \text { (water }\right)^{0.5}\right]}{\text { Line 2 Result }} \times \frac{\text { Line 3 Result }}{\left[\mathrm{ft}^{2}\right]} \times \frac{\text { CFMc }}{\left[(\text { in. of water })^{0.5}\right]}=\frac{}{[\mathrm{cfm}]}$

Overview

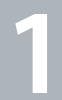

Option A:

Simplified

Method

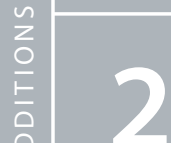

Option B:

Simulation

Method

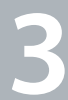

Option C.

Leverage

Example

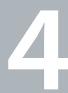

Option A

Simplified

Method

Option B:

Simulation

Method

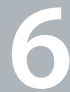

Option C:

Leverage

Example

References

\section{Step 4 Select a flow-normalized climate factor}

Choose the appropriate flow-normalized climate factor, $\mathrm{F}_{\mathrm{CF}}$, from Table 1-2. (Choose the city with the most similar climate. See Appendix D for a U.S. map of the DOE climate zones and representative cities.)

Flow-normalized climate factor, $\mathbf{F}_{\mathrm{CF}}[\mathrm{MMBtu} \cdot$ day/h/cfm]:

Line 6

\section{Step 5 Identify a time-of-day multiplier}

If you know your door typically opens and closes within specific timeframes, you can use a time-of-day multiplier, $\mathrm{M}_{\mathrm{T}}$, from Table 1-3 to adjust your estimate. If you do not have this information, assume a time-of-day multiplier of 1.

Time-of-day multiplier, $\mathbf{M}_{\mathbf{T}}$ :

Line 7

\section{Step 6 Estimate your energy savings potential}

Use the following equation to estimate the whole-building energy savings potential, $\mathrm{E}_{\text {savings, }}$ associated with your vestibule addition:

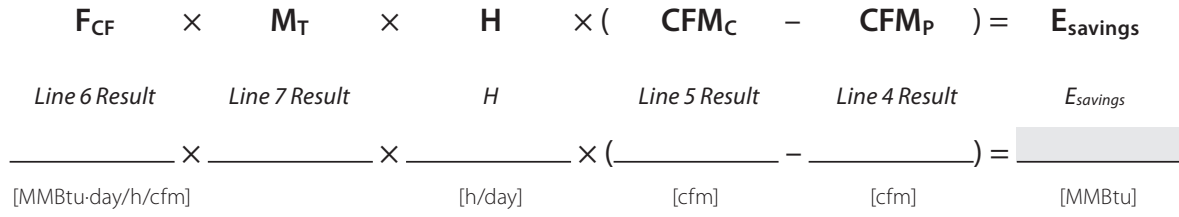

Line 8

\section{Step $7 \quad$ Select cooling and heating fraction multipliers}

Select the appropriate cooling, $M_{\mathrm{CLG}}$, and heating, $\mathrm{M}_{\mathrm{HTG}}$, fraction multipliers from Table 1-4. (Choose the city with the most similar climate. See Appendix D for a U.S. map of the DOE climate zones and representative cities.)

Cooling fraction multiplier, $\mathrm{M}_{\mathrm{CLG}}$ :

Line 9

Heating fraction multiplier, $\mathbf{M}_{\mathrm{HTG}}$ :

Line 10

\section{Step $8 \quad$ Estimate the costs associated with cooling and heating}

According to your utility rate structure, estimate the costs of electricity for cooling, $\mathrm{C}_{\mathrm{CLG}}$, and natural gas for heating, $\mathrm{C}_{\mathrm{HTG}}$, for your scenarios.

Cost of electricity for cooling, $\mathrm{C}_{\mathrm{CLG}}[\$ / \mathrm{kWh}]$ :

Line 11

Cost of natural gas for heating, $\mathrm{C}_{\mathrm{HTG}}[\$ /$ therm]:

Line 12

\section{Step 9 Estimate your cost savings potential}

Use the following equation to estimate the energy cost savings potential, $C_{\text {savings: }}$ :

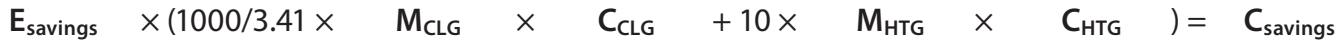

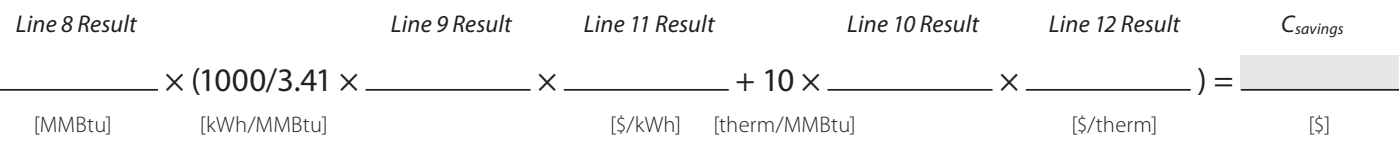




\section{Appendix F - Worksheet for Section 3}

Vestibule Additions: Leveraging an Example Simulation for Supermarkets

This worksheet can be used in combination with Section 3 of the guide.

\section{Step 1 Estimate your percent energy savings potential}

Identify the appropriate percent energy savings potential, E\%savings, from Table 3-1. (Choose the city with the most similar climate. See Appendix D for a U.S. map of the DOE climate zones and representative cities.)

Percent energy savings potential for supermarket vestibule additions, E$_{\% \text { savings }}[\%]$ :

\section{Step 2 Estimate your energy savings potential}

The following equation can be used to determine the estimated annual whole-building energy savings potential, $E_{\text {savings: }}$

\begin{tabular}{|c|c|c|c|c|}
\hline $\mathrm{E}_{\% \text { savings }}$ & $/ 100 \times$ & $E_{\text {total }}$ & $=$ & $E_{\text {savings }}$ \\
\hline Line 1 Result & & $E_{\text {total }}$ & & Esavings \\
\hline
\end{tabular}

\section{Step 3 Select cooling and heating fraction multipliers}

Select the appropriate cooling, $\mathrm{M}_{\mathrm{CLG}}$, and heating, $\mathrm{M}_{\mathrm{HTG}}$, fraction multipliers from Table 3-2. (Choose the city with the most similar climate. See Appendix D for a U.S. map of the DOE climate zones and representative cities.)

$$
\begin{array}{ll}
\text { Cooling fraction multiplier, } \mathbf{M}_{\mathrm{CLG}}: & \text { Line } 3 \\
\text { Heating fraction multiplier, } \mathbf{M}_{\mathrm{HTG}}: & \text { Line } 4
\end{array}
$$

\section{Step $4 \quad$ Estimate the costs associated with cooling and heating}

According to your utility rate structure, estimate the costs of electricity for cooling, $\mathrm{C}_{\mathrm{CLG}}$, and natural gas for heating, $\mathrm{C}_{\mathrm{HTG}}$, for your scenarios.

\section{Step 5 Estimate your cost savings potential}

Use the following equation to estimate the energy cost savings potential, $C_{\text {savings: }}$ :

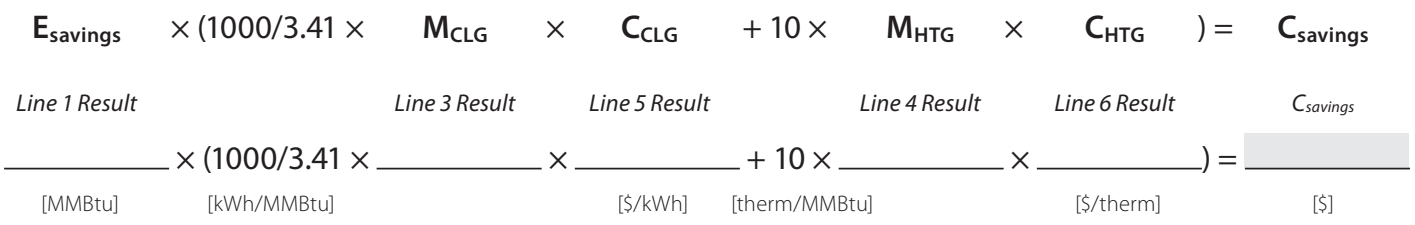

Line 7 


\section{Appendix G - Worksheet for Section 4 \\ Door Operation Changes: Simplified Method}

Overview

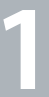

Option A:

Simplified

Method

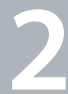

Option B:

Simulation

Method

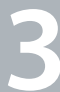

Option C

Leverage

Example

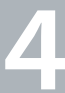

Option A

Simplified

Method

Option B:

Simulation

Method

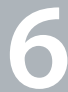

Option C

Leverage

Example

References

Appendices
This worksheet can be used in combination with Section 4 of the guide.

\section{Step 1 Select an area-normalized climate factor}

Choose the appropriate area-normalized climate factor, $F_{C A}$, from Table 4-1. (Choose the city with the most similar climate. See Appendix D for a U.S. map of the DOE climate zones and representative cities.)

Area-normalized climate factor, $\mathrm{F}_{\mathrm{CA}}\left[\mathrm{MMBtu} \cdot\right.$ day $\left./ \mathrm{h} / \mathrm{ft}^{2}\right]$ :

Line 1

\section{Step 2 Identify a time-of-day multiplier}

If you know your door typically opens and closes within specific timeframes, you can use a time-of-day multiplier, $\mathrm{M}_{\mathrm{T}}$, from Table 4-2 to adjust your estimate. If you do not have this information, assume a time-of-day multiplier of 1.

Time-of-day multiplier, $\mathbf{M}_{\mathrm{T}}$ :

Line 2

\section{Step 3 Identify your current and proposed strategies}

Identify your current door operation strategy:

Effective door area for current strategy, $\mathbf{A}_{c}\left[\mathrm{ft}^{2}\right]$ :

Line 3

Hours per day door is left open for current strategy, $\mathrm{H}_{\mathrm{c}}[\mathrm{h} /$ day $]$ :

Line 4

Identify a proposed alternative:

Effective door area for proposed strategy, $A_{p}\left[\mathrm{ft}^{2}\right]$ :

Line 5

Hours per day door is left open for proposed strategy, $\mathrm{H}_{\mathrm{P}}[\mathrm{h} /$ day]:

Line 6

\section{Step 4 Estimate your energy savings potential}

Use the following equation to estimate the whole-building energy savings potential, $\mathrm{E}_{\text {savings, }}$ associated with your alternative door operation:

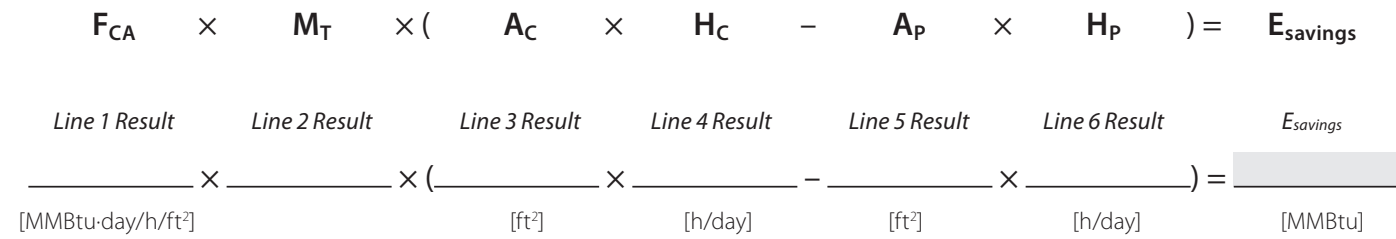

Line 7

\section{Step 5 Select cooling and heating fraction multipliers}

Select the appropriate cooling, $\mathrm{M}_{\mathrm{CLG}}$, and heating, $\mathrm{M}_{\mathrm{HTG}}$, fraction multipliers from Table 4-3. (Choose the city with the most similar climate. See Appendix D for a U.S. map of the DOE climate zones and representative cities.)

$$
\text { Cooling fraction multiplier, } \mathbf{M}_{\mathrm{CLG}} \text { : }
$$




\section{Step 6 Estimate the costs associated with cooling and heating}

According to your utility rate structure, estimate the costs of electricity for cooling, $\mathrm{C}_{\mathrm{CLG}}$, and natural gas for heating, $\mathrm{C}_{\mathrm{HTG}}$, for your scenarios.

$$
\text { Cost of electricity for cooling, } \mathrm{C}_{\mathrm{CLG}}[\$ \mathrm{kWh}] \text { : }
$$

Cost of natural gas for heating, $\mathrm{C}_{\mathrm{HTG}}[\mathbf{\$} /$ therm]:
Line 10

Line 11

\section{Step $7 \quad$ Estimate your cost savings potential}

Use the following equation to estimate the energy cost savings potential, $C_{\text {savings: }}$

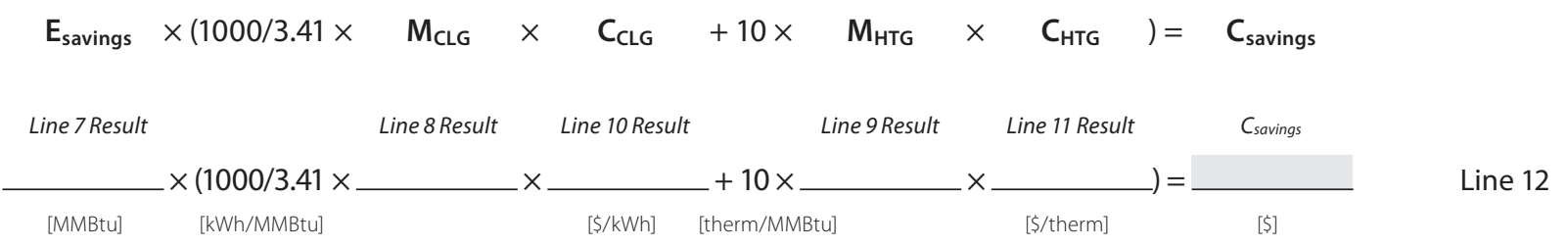




\section{Appendix $\mathbf{H}$ - Worksheet for Section 6 \\ Door Operation Changes: Leveraging an Example Simulation for Large Retail Buildings}

Overview

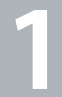

Option A:

Simplified

Method

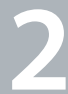

Option B:

Simulation

Method

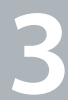

Option C:

Leverage

Example

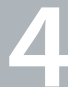

Option A:

Simplified

Method

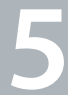

Option B.

Simulation

Method

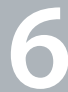

Option C:

Leverage

Example

References

Appendices
This worksheet can be used in combination with Section 6 of the guide.

\section{Step 1 Select an energy savings factor}

Choose the appropriate energy savings factor, $\mathrm{F}_{\mathrm{ES}}$, from Table 6-2. (Choose the city with the most similar climate. See Appendix D for a U.S. map of the DOE climate zones and representative cities.)

Energy savings factor, $\mathrm{F}_{\mathrm{ES}}\left[\mathrm{MMBtu} \cdot \mathrm{day} / \mathrm{h} / \mathrm{ft}^{2}\right]$ :

Line 1

\section{Step 2 Identify your current and proposed strategies}

Identify your current door operation strategy:

Effective door area for current strategy, $\mathbf{A}_{C}\left[\mathrm{ft}^{2}\right]$ :

Line 2

Hours per day door is left open for current strategy, $\mathrm{H}_{\mathrm{c}}[\mathrm{h} /$ day]:

Line 3

Identify a proposed alternative:

Effective door area for proposed strategy, $A_{p}\left[\mathrm{ft}^{2}\right]$ :

Line 4

Hours per day door is left open for proposed strategy, $\mathrm{H}_{\mathrm{P}}[\mathrm{h} /$ day]:

Line 5

\section{Step 3 Estimate your energy savings potential}

Use the following equation to estimate the whole-building energy savings potential, $\mathrm{E}_{\mathrm{savings}}$, associated with your alternative door operation:

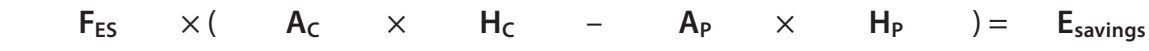

$\frac{\text { Line } 1 \text { Result }}{\left[\mathrm{MMBtu} \cdot \mathrm{day} / \mathrm{h} / \mathrm{ft}^{2}\right]} \times\left(\frac{\text { Line 2 Result }}{\left[\mathrm{ft}^{2}\right]} \times \frac{\text { Line 3Result }}{[\mathrm{h} / \mathrm{day}]}-\frac{\text { Line 4Result }}{\left[\mathrm{ft}^{2}\right]} \times \frac{\text { Line } 5 \text { Result }}{[\mathrm{h} / \mathrm{day}]}\right)=\frac{E_{\text {savings }}}{[\mathrm{MMBtu}]}$

Line 6

\section{Step 4 Select cooling and heating fraction multipliers}

Select the appropriate cooling, $\mathrm{M}_{\mathrm{CLG}}$, and heating, $\mathrm{M}_{\mathrm{HTG}}$, fraction multipliers from Table 6-3. (Choose the city with the most similar climate. See Appendix D for a U.S. map of the DOE climate zones and representative cities.)

Cooling fraction multiplier, $\mathrm{M}_{\mathrm{CLG}}$ :

Line 7

Heating fraction multiplier, $\mathbf{M}_{\mathrm{HTG}}$ :

Line 8

\section{Step 5 Estimate the costs associated with cooling and heating}

According to your utility rate structure, estimate the costs of electricity for cooling, $\mathrm{C}_{\mathrm{CLG}}$, and natural gas for heating, $\mathrm{C}_{\mathrm{HTG}}$, for your scenarios.
Line 9

Cost of natural gas for heating, $\mathrm{C}_{\mathrm{HTG}}[\$ /$ therm]: 
Use the following equation to estimate the energy cost savings potential, $C_{\text {savings: }}$ :

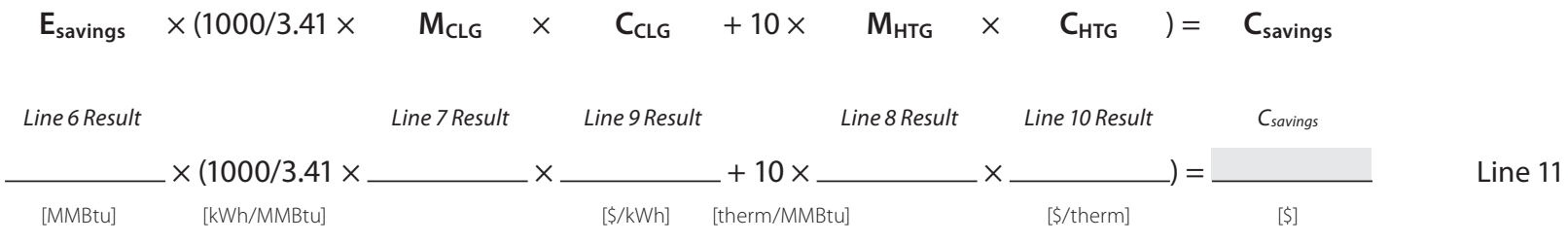




\section{National Renewable Energy Laboratory}

15013 Denver West Parkway, Golden, Colorado 80401

303-275-3000 • www.nrel.gov

NREL is a national laboratory of the U.S. Department of Energy

Office of Energy Efficiency and Renewable Energy

Operated by the Alliance for Sustainable Energy, LLC

Front page photos by: Patrick Corkery, NREL/PIX16560;

NREL/BK-5500-52290 • March 2012 